Provided for non-commercial research and education use. Not for reproduction, distribution or commercial use.

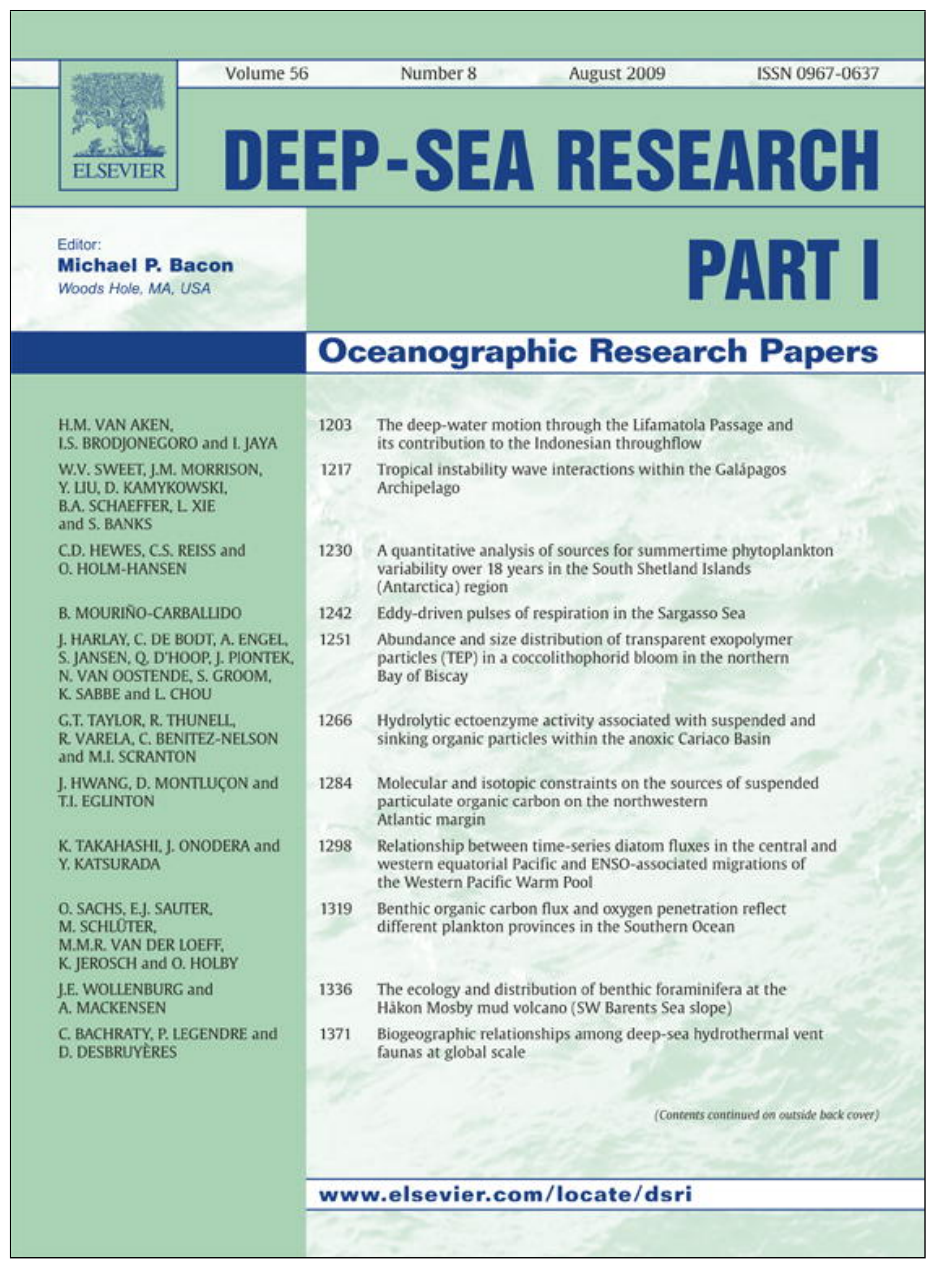

This article appeared in a journal published by Elsevier. The attached copy is furnished to the author for internal non-commercial research and education use, including for instruction at the authors institution and sharing with colleagues.

Other uses, including reproduction and distribution, or selling or licensing copies, or posting to personal, institutional or third party websites are prohibited.

In most cases authors are permitted to post their version of the article (e.g. in Word or Tex form) to their personal website or institutional repository. Authors requiring further information regarding Elsevier's archiving and manuscript policies are encouraged to visit:

http://www.elsevier.com/copyright 


\title{
Abundance and size distribution of transparent exopolymer particles (TEP) in a coccolithophorid bloom in the northern Bay of Biscay
}

\author{
Jérôme Harlay $^{\mathrm{a}, *}$, Caroline De Bodt ${ }^{\mathrm{a}, 1}$, Anja Engel ${ }^{\mathrm{b}, 2}$, Sandra Jansen ${ }^{\mathrm{b}, 2}$, Quentin d'Hoop ${ }^{\mathrm{a}, 1}$, \\ Judith Piontek $^{\mathrm{b}, 2}$, Nicolas Van Oostende ${ }^{\mathrm{c}, 3}$, Steve Groom ${ }^{\mathrm{d}, 4}$, Koen Sabbe ${ }^{\mathrm{c}, 3}$, Lei Chou ${ }^{\mathrm{a}, 1}$ \\ a Laboratoire d'Océanographie Chimique et Géochimie des Eaux_Université Libre de Bruxelles (ULB)_Campus de la Plaine (Building B/C, 5th level), CP208, \\ boulevard du Triomphe, B-1050 Brussels, Belgium \\ ${ }^{\mathrm{b}}$ HGF Young Investigators Group, Global change and the future marine carbon cycle_Alfred Wegener Institute (AWI)—Am Handelshafen 12 -D-27570 \\ Bremerhaven, Germany \\ ${ }^{\mathrm{c}}$ Protistology \& Aquatic Ecology_Ghent University (UGhent)—Krijgslaan 281-S8, B-9000 Ghent, Belgium \\ ${ }^{\mathrm{d}}$ Remote Sensing Group_Plymouth Marine Laboratory (PML)_Prospect Place, The Hoe, Plymouth PL1 3DH, UK
}

\section{A R T I C L E I N F O}

\section{Article history:}

Received 21 July 2008

Received in revised form

13 January 2009

Accepted 22 January 2009

Available online 6 February 2009

Keywords:

TEP

Carbon

Coccolithophores

North Atlantic Ocean

\begin{abstract}
A B S T R A C T
The distribution of transparent exopolymer particles (TEP) was investigated during a coccolithophorid bloom in the northern Bay of Biscay (North Atlantic Ocean) in early June 2006. MODIS chlorophyll-a (Chl- $a$ ) and reflectance images before and during the cruise were used to localize areas of important biological activity and high reflectance (HR). TEP profiles along the continental margin, determined using microscopic ( $\left.\mathrm{TEP}_{\text {micro }}\right)$ and colorimetric ( $\left.\mathrm{TEP}_{\text {color }}\right)$ methods, showed abundant $\left(6.1 \times 10^{6}-4.4 \times 10^{7} \mathrm{~L}^{-1}\right)$ and relatively small $(0.5-20 \mu \mathrm{m})$ particles, leading to a low total volume fraction $(0.05-2.2 \mathrm{ppm})$ of $\mathrm{TEP}_{\text {micro }}$ and similar vertical profiles of TEP color Estimates of carbon content in TEP (TEP-C) derived from the microscopic approach yielded surface concentration of $1.50 \mu \mathrm{mol} \mathrm{CL}{ }^{-1}$. The contribution of TEP-C to particulate organic carbon (POC) was estimated to be $12 \%$ (molar C ratio) during this survey. Our results suggest that TEP formation is a probable first step to rapid and efficient export of $\mathrm{C}$ during declining coccolithophorid blooms.
\end{abstract}

(c) 2009 Elsevier Ltd. All rights reserved.

\section{Introduction}

During the last 15 years, many field studies have pointed out the importance of exopolymer substances (EPS) in natural systems (Passow, 2002; Wotton, 2004). A large fraction of EPS consists of carbohydrates that are released during and after phytoplankton blooms (Myklestad, 1995). Because of their physico-chemical

\footnotetext{
* Corresponding author. Tel.: +32265052 78; fax: +3226505228.

E-mail address: jharlay@ulb.ac.be (J. Harlay).

1 Tel.: +32 26505278 ; fax: +32 26505228 .

2 Tel.: +4947148311444 ; fax: +4947148311149 .

3 Tel.: +3292649629; fax: +3292648599.

${ }^{4}$ Tel.: +441752 633150; fax: +441752633101.
}

characteristics, EPS are able to stick to each other and form networks of fibrils (Leppard, 1995) or colloids (Kepkay, 1994). They are thereby transferred from the dissolved to the particulate organic matter pool. Transparent exopolymer particles (TEP) merge the two properties of (1) being retained onto $0.4 \mu \mathrm{m}$ membrane filters and (2) being stainable by Alcian Blue, a specific dye for acidic $\left(-\mathrm{COO}^{-}\right)$or sulphated $\left(-\mathrm{O}-\mathrm{SO}_{3}^{-}\right)$reactive groups of carbohydrates (Alldredge et al., 1993). Several studies indicate that TEP are natural constituents of the bulk particulate matter in marine (Passow and Alldredge, 1995b; Mari and Kiorboe, 1996; Krembs and Engel, 2001; Garcia et al., 2002; Engel, 2004; Brussaard et al., 2005; Radic et al., 2005; Shackelford and Cowen, 2006; Prieto et al., 2006; Sugimoto et al., 2007) and freshwater 
(Logan et al., 1995; Grossart et al., 1997; Berman and Viner-Mozzini, 2001; Arruda-Fatibello et al., 2004) ecosystems. Most of the field sites where TEP have been described so far were dominated by diatoms, dinoflagellates or cyanobacteria.

However, nutrient-induced blooms of Emiliania huxleyi in mesocosms suggested that coccolithophores could also be responsible for high concentrations of TEP (Engel et al., 2004). The dynamics of such an induced E. huxleyi bloom may be extrapolated to the field to some extent. As described in this mesocosm study, phytoplankton blooms start with an exponential phase during which cell division occurs under nutrient-replete conditions (Delille et al., 2005; Engel et al., 2005). The exhaustion of nutrients coincides with the beginning of the stationary phase. Cell division is then considerably reduced while large amounts of coccoliths are still produced by the coccolithophores. During the stationary phase, the cells are generally covered by several layers of coccoliths and the distal ones are released into the water column when new ones are produced (Paasche, 2002). This phase is often associated with the decay of the bloom, when high abundance of E. huxleyi coincides with those of viruses, enhancing viral infection and bloom termination (Catsberg et al., 2001; Jacquet et al., 2002). The persistence of coccolithophorid blooms after nutrient exhaustion is haphazard and patchy in natural environments. The release of large amounts of coccoliths, in particular by E. huxleyi (Paasche, 2002), modifies the optical properties of surface seawater and leads to high reflectance (HR) patches that can be observed by remote sensing (GREPMA, 1988; Holligan et al., 1983, 1993a; Brown and Yoder, 1994).

Excess carbon production compared to what is expected according to Redfield's stoichiometry was pointed out in phytoplankton blooms during mesocosm experiments (Engel et al., 2002, 2005; Delille et al., 2005). Using a modelling approach based on mesocosm observations, Schartau et al. (2007) established a link between the excess of dissolved inorganic carbon (DIC) uptake (termed carbon over-consumption) and the rapid formation of TEP-C through dissolved organic carbon (DOC) exudation by phytoplankton after nutrient exhaustion. Thus, in the stationary phase, carbon cycling is uncoupled from nutrient availability because of continuous production and release of organic carbon by the cells. Because TEP have high C:N ratios (Mari, 1999; Engel and Passow, 2001; Mari et al., 2001), they are thought to contribute to particulate organic carbon (POC) rather than to the particulate nitrogen pool and can therefore increase $\mathrm{C}: \mathrm{N}$ ratios of the particulate organic matter (POM).

This study investigated the contribution of coccolithophores to the TEP production, the pattern of TEP concentrations and the size distribution during a coccolithophorid bloom in the northern Bay of Biscay (North Atlantic Ocean, early June 2006). Chemical and biological parameters as well as remote sensing images are included in order to better describe phytoplankton bloom dynamics. Here, we present TEP profiles at different stations in the northern Bay of Biscay and estimate the contribution of TEP to POC.

\section{Materials and methods}

\subsection{Study site and field sampling}

The continental shelf of the northern Bay of Biscay is located south of Ireland and west of France, where a steep slope separates the abyssal plain from the continental plateau (Fig. 1). Samples were collected between 31 May and 9 June 2006. Images from the NASA Moderate Resolution Imaging Spectroradiometer (MODIS) instrument onboard the Aqua platform were processed in near-real time and sent via e-mail to the research vessel. Chlorophyll- $a$ (Chl- $a$ ) concentration was computed using the MODIS OC3 band switching algorithm (see O'Reilly et al., 1998). False colour composites were produced from the 443, 490 and $551 \mathrm{~nm}$ channels displayed as the red, green and blue components of a colour image. These reflectance images show the approximate "colour of the ocean" and the magnitude of coccolithophore scattering as blue-white areas (Holligan et al., 1983). The Chl- $a$ images revealed two zones in terms of phytoplankton biomass (Fig. 1a). In the western zone, Chl- $a$ was low, while in the eastern part corresponding to the continental shelf and margins, Chl- $a$ levels were higher, indicating enhanced biological activity. HR was mainly observed inshore of the $200 \mathrm{~m}$ isobath, the bathymetric boundary between the open ocean and the continental plateau (Fig. 1b), except south of $48.3^{\circ} \mathrm{N}$ where HR extended over the slope.

Sampling stations (Fig. 1) were located at the continental margin over the continental shelf (stations 1, 4, 7 and 8 ) and along the shelf-break, situated at about $500 \mathrm{~m}$ (stations 2 and 5) and $1200 \mathrm{~m}$ depth (stations 3 and 6). A HR patch was localized by remote sensing at stations 4,5 , 7 and 8 and was sampled with adjacent stations (Fig. 1b). The cruise was split into two legs (first leg: 3 days, second leg: 4 days). During the second leg some stations ( 1 and 4 ) were revisited after 9 and 6 days and are referred to as stations 1 bis and 4 bis, respectively.

A Seabird CTD system, equipped with a 12 Niskin bottle $(10 \mathrm{~L})$ rosette sampler, was used to determine depth profiles of temperature and salinity, and to collect seawater for chemical and biological analyses. At each station, water was collected in the morning at 3,10,20,40, $60,80,100$ and $150 \mathrm{~m}$ depths. Some additional depths $(30,50$ and $120 \mathrm{~m})$ were also sampled in the surface layer for some stations. All samples were processed onboard immediately after sampling.

\subsection{Chlorophyll-a (Chl-a) and diagnostic pigments}

The concentration of Chl- $a$ was determined from $250 \mathrm{~mL}$ seawater filtered onto glass fibre filters (Whatman $\mathrm{GF} / \mathrm{F}$ ) under low vacuum, wrapped in aluminium foil and stored at $-20^{\circ} \mathrm{C}$ until analysis. Pigment extraction was realized in $10 \mathrm{~mL}$ of $90 \%$ acetone. Filters were kept overnight in the dark at $-20^{\circ} \mathrm{C}$ and were centrifuged for $10 \mathrm{~min}$ at $5000 \mathrm{rpm}$ at $4{ }^{\circ} \mathrm{C}$ prior to measurement. Chl- $a$ concentration was determined fluorimetrically (Shimatzu RF-1501 spectrofluorophotometer), together with total 

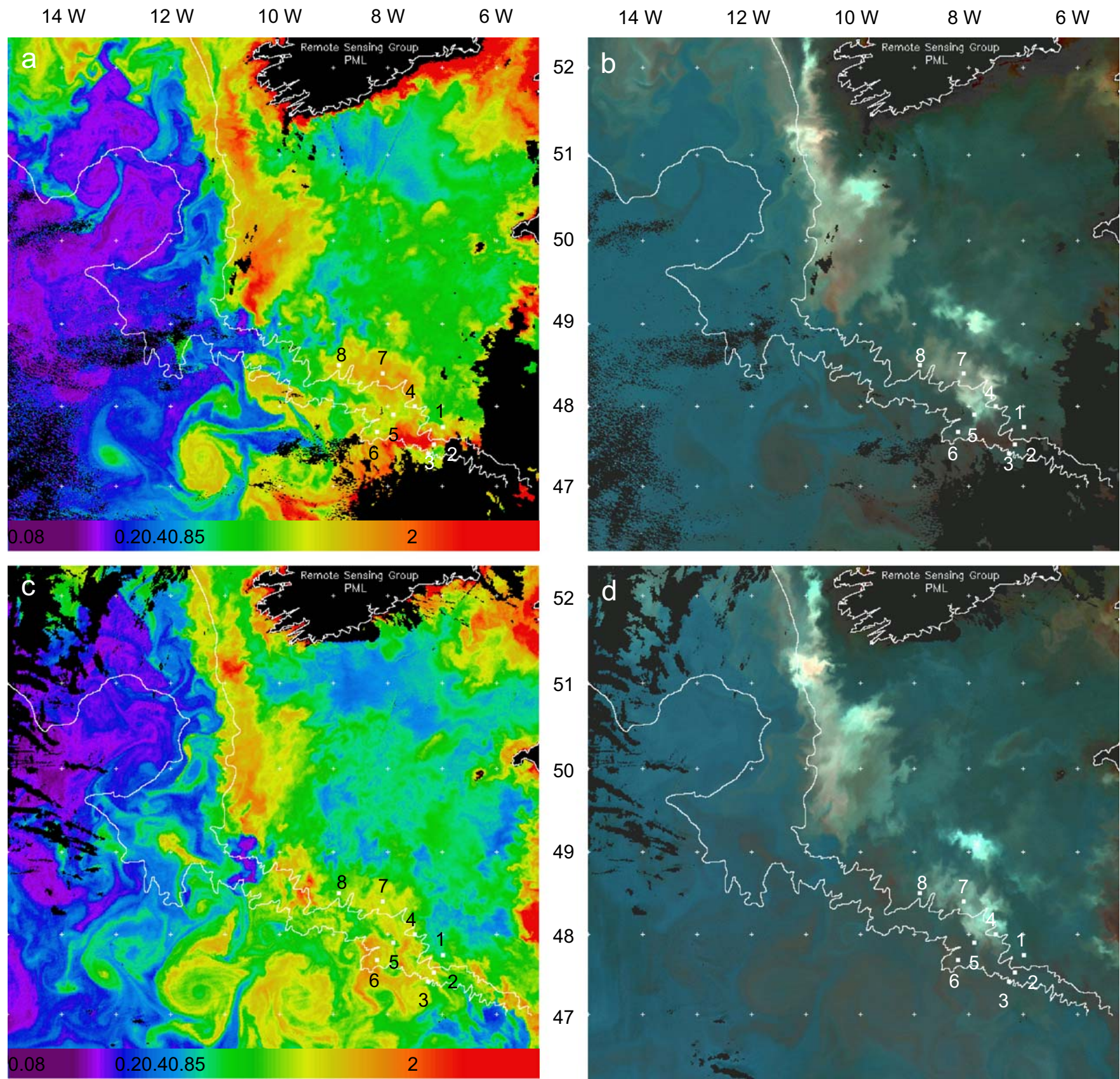

Fig. 1. Locations of the sampling stations along the $200 \mathrm{~m}$ (stations 1, 4, 5 and 8) and $2000 \mathrm{~m}$ (stations 3 and 6 ) isobaths superimposed on MODIS images of Chl- $a$ (left) and reflectance (right) satellite images on 1 June 2006 (a, b) and on the 5 June 2006 (c, d) in the northern Bay of Biscay. The Chl- $a$ concentrations are graphically represented by the gradient from violet to red (with units $\mathrm{mg} \mathrm{Chl}-a_{\mathrm{m}}^{-3}$ ). The high reflectance patches are represented by the brighter blue-white areas on the reflectance images.

phaeophytin concentration after acidification $(\mathrm{HCl}, 0.1 \mathrm{~N})$, according to Yentsch and Menzel (1963).

Separation of the algal pigments was performed using a high performance liquid chromatographic (HPLC) method based on Wright and Jeffrey (1997). Between 0.5 and $3.5 \mathrm{~L}$ of $* *$ seawater were filtered through glass fiber filters (Whatmann GF/F). The filters were stored in liquid nitrogen onboard until analysis. Extraction of the pigments was performed in a $90 \%$ aquaeous aceton solution. Standard pigment mixtures were run together with the samples to allow identification and quantification of the detected pigment peaks in the chromatogram. The analysis of the diagnostic pigments for coccolithophores (19'-hexanoyloxyfucoxanthin, HexaFx) and diatoms (fucoxanthin, Fx) allowed the computation of the HexaFx:Fx ratio to assess the relative contribution of coccolithophores to the phytoplankton pool (Barlow et al., 1993, 1998). Higher values of this ratio indicate higher contributions of coccolithophores in the phytoplankton pool.

\subsection{Dissolved phosphorus}

Dissolved phosphate concentration was measured colorimetrically after filtration through a $0.4 \mu \mathrm{m}$ 
Nuclepore filter, using the molybdate blue method described in Grasshoff et al. (1983). The detection limit is $10 \mathrm{nM}$ using a $10-\mathrm{cm}$ optical cell.

\subsection{Particulate organic carbon (POC)}

Seawater (200-2000 mL) was filtered through precombusted $\left(4 \mathrm{~h}, 500^{\circ} \mathrm{C}\right) \mathrm{GF} / \mathrm{F}$ filters. The samples were stored at $-20^{\circ} \mathrm{C}$ until analysis. Within 3 months after the cruise, the filters were dried overnight at $50{ }^{\circ} \mathrm{C}$ prior to analysis. POC was determined using a Fisons NA-1500 elemental analyser after carbonate removal from the filters by $\mathrm{HCl}$ fumes overnight. Four to five standards of certified reference stream sediment (STSD-2) from the Geological Survey of Canada, together with 3-4 blank filters, were used for the calibration. POC was sampled down to $80 \mathrm{~m}$ for stations 4 and $4 \mathrm{~b}, 100 \mathrm{~m}$ for station $1,120 \mathrm{~m}$ for station 1bis, $150 \mathrm{~m}$ for stations 7 and 8 and down to $540 \mathrm{~m}$ for station 2 (of which only the uppermost $150 \mathrm{~m}$ are presented). No data were obtained for 30,40 or $60 \mathrm{~m}$ at station 1 because of technical problems during the analysis.

\subsection{Transparent exopolymer particles (TEP)}

\subsubsection{Colorimetric determination of TEP (TEP color $)$}

Triplicates of $5-250 \mathrm{~mL}$ each were filtered ( $<200 \mathrm{mbar}$ ) onto $25 \mathrm{~mm}$ Nuclepore membrane filters $(0.4 \mu \mathrm{m}$ pore size $)$ for the colorimetric determination of TEP (TEP color), according to Passow and Alldredge (1995a). The filters were stained with $0.5 \mathrm{~mL}$ Alcian Blue (Alldredge et al., 1993) and stored frozen at $-20^{\circ} \mathrm{C}$ and analysed within 6 weeks. Prior to spectrophotometric analysis $(787 \mathrm{~nm}$ in a $1 \mathrm{~cm}$ path-length cell), the filters were soaked for $2 \mathrm{~h}$ in $80 \% \mathrm{H}_{2} \mathrm{SO}_{4}$. Light absorbance was corrected for the adsorption of Alcian Blue on blank filters. $\mathrm{TEP}_{\text {color }}$ is given in relative units, i.e. in \% of the highest absorbance at each station (Table 1).

\subsubsection{Microscopic determination of TEP size spectrum}

Microscopic analysis of TEP was conducted after Engel (2009). Samples of $5-200 \mathrm{~mL}$ of seawater were filtered $(<200 \mathrm{mbar}$ ) onto $0.4 \mu \mathrm{m}$ Nuclepore filters within $1 \mathrm{~h}$ after sampling and stained with $0.5 \mathrm{~mL}$ Alcian Blue $(\mathrm{pH}$ 2.5) (Alldredge et al., 1993). The filters were prepared in duplicate, placed onto semi-permanent TEP slides (CytoClear) and stored frozen at $-20^{\circ} \mathrm{C}$ until analysis. TEP slides were transferred to a compound light microscope and screened by a digital AxioCam HRc camera (Zeiss) with a $200-400 \times$ magnification. About 30 pictures per filter were randomly taken in a cross section. The composite pictures were split into red, green and blue components (RGB Split) using the image analysis program WCIF Image (a public domain program developed at the US National Institute of Health-http://www.uhnresearch. ca/facilities/wcif/fdownload.html-courtesy of Wayne Rasband, National Institute of Mental Health, Bethesda, MD, USA). The red segment accentuates the blue-stained TEP and was used for further analysis. TEP with an area larger than $0.2 \mu \mathrm{m}^{2}$ were enumerated and sized for individual area and major cross section. The equivalent spherical diameter (ESD) was calculated for individual particles from area measurements, leading to a range of $0.5-80 \mu \mathrm{m}$ (ESD).

TEP were classified according to their ESD into 20 logarithmic size classes (Mari and Burd, 1998). TEP size distributions were described using a power-law of the type $d N / d\left(d_{p}\right)=k d_{p}{ }^{\delta}$, where $d N$ is the number of particles per unit volume in the size range $d_{p}$ to $\left\lfloor d_{p}+d\left(d_{p}\right)\right\rfloor$. The constant, $k$, depends on the concentration of particles and the spectral slope, $\delta$ (with $\delta<0$ ), describes the size distribution. Both constants were derived from regressions of $\left.\log \mid d N / d\left(d_{p}\right)\right\rfloor$ versus $\log \left|d_{p}\right|$. $\delta$ is related to the slope of the cumulative size distribution

Table 1

Maximum values in the upper $160 \mathrm{~m}$ of some parameters for each station.

\begin{tabular}{|c|c|c|c|c|c|c|c|c|c|}
\hline Stations & Date & $\begin{array}{l}Z_{1} \% \\
(\mathrm{~m})\end{array}$ & $\begin{array}{l}\text { Chl- } a \text { max } \\
\left(\mu \mathrm{gL}^{-1}\right)\end{array}$ & $\begin{array}{l}\text { POC max } \\
(\mu \mathrm{M})\end{array}$ & $\begin{array}{l}\text { TEP }_{\text {color }} \\
\text { (Abs) per L } \\
\text { of SW }\end{array}$ & $\begin{array}{l}\text { Area } \\
\mathrm{TEP}_{\text {micro }} \\
\left(\mu \mathrm{m}^{2} \mathrm{~mL}^{-1}\right)\end{array}$ & $\begin{array}{l}\text { Abund. } \\
\text { TEP }_{\text {micro }} \\
\left(\mathrm{mL}^{-1}\right)\end{array}$ & $\begin{array}{l}\text { Conc. } \\
\text { TEP }_{\text {micro }} \\
\text { (ppm) }\end{array}$ & 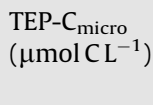 \\
\hline 1 & 2006-05-31 & 30 & 1.49 & 11.7 & 4.10 & 11.6 & $43.71 \times 10^{3}$ & 2.22 & 5.25 \\
\hline 1 bis & 2006-06-09 & 37 & 0.89 & 17.3 & 21.72 & 4.9 & $15.40 \times 10^{3}$ & 0.98 & 2.05 \\
\hline 2 & 2006-06-01 & 31 & 2.01 & 14.8 & 31.67 & 2.8 & $9.67 \times 10^{3}$ & 1.08 & 1.57 \\
\hline 3 & 2006-06-01 & & 1.47 & n.d. & 7.55 & 3.2 & $6.86 \times 10^{3}$ & 0.33 & 0.78 \\
\hline 4 & 2006-06-01 & 26 & 1.46 & 16.0 & 1.79 & 3.2 & $6.23 \times 10^{3}$ & 1.30 & 1.63 \\
\hline $4 \mathrm{bis}^{\mathrm{a}}$ & 2006-06-08 & 27 & 1.33 & 11.2 & 8.17 & 24.1 & $2.02 \times 10^{3}$ & 1.47 & 2.42 \\
\hline 5 & 2006-06-02 & & 1.3 & n.d. & 1.41 & n.d. & n.d. & n.d. & n.d. \\
\hline 6 & 2006-06-07 & & 1.62 & n.d. & 14.93 & n.d. & n.d. & n.d. & n.d. \\
\hline $7^{\mathrm{a}}$ & 2006-06-07 & 26 & 1.43 & 24.6 & 4.93 & 37.3 & $18.92 \times 10^{3}$ & 0.87 & 1.85 \\
\hline $8^{a}$ & 2006-06-06 & 34 & 0.8 & 14.6 & 2.10 & 11.3 & $6.13 \times 10^{3}$ & 0.47 & 0.68 \\
\hline
\end{tabular}

The thickness of the photic zone refers to the depth at which $1 \%$ of the incoming PAR is measured $\left(Z_{1 \%}\right) . \mathrm{Chl}_{-} a_{\max }\left(\mu \mathrm{g} \mathrm{L} \mathrm{L}^{-1}\right)$ and POC $\max \left(\mu \mathrm{mol} \mathrm{L} \mathrm{L}^{-1}\right)$ represent the highest levels of Chl- $a$ and POC per profile. The values of the maximum of absorbance at each station (normalized per liter of seawater) are quoted as $\mathrm{TEP}_{\text {color }}(\mathrm{Abs})$ for the colorimetric determination of TEP (TEP color $)$. The following columns present the maxima of total area $\left(\mu \mathrm{m}^{2} \mathrm{~mL}^{-1}\right)$, abundance $\left(\mathrm{mL}^{-1}\right)$ and carbon content estimate $\left(\mu \mathrm{mol} \mathrm{CL} \mathrm{L}^{-1}\right)$ of the TEP micro.n.d., parameter not determined.

a Stations located within the HR patch. 
$N=\operatorname{ad}_{p}{ }^{\beta}$ by $\delta=\beta+1$. Spectral slopes were used to describe the TEP size distribution, an increase in $\delta$ being due to an increase of the fraction of large TEP. The volume concentration is defined here as the mean volume of the particles that belong to a size class in the sample; changes of this quantity indicate some changes in the dynamics of particles due to aggregation/ disaggregation processes.

\subsubsection{Estimation of TEP carbon concentration (TEP-C)}

TEP-C content (TEP- $\left.C_{\text {micro, }} \mu \mathrm{M}\right)$ was assessed by the microscopic approach assuming that the volume of TEP is proportional to $r^{D}$, where $r$ is the equivalent spherical radius in $\mu \mathrm{m}$ and $D$ the fractal dimension associated with the size distribution of particles. Therefore TEP- $\mathrm{C}_{\text {micro }}$ was determined from TEP size spectra according to Mari
(1999). For each sample, $D$ was deduced from the spectral slope, $\delta$, according to the semi-empirical relationship (Burd and Jackson, unpublished data, as referred to in Mari and Burd, 1998)

$D=(64-\delta) / 26.2$

Thus, TEP- $\mathrm{C}_{\text {micro }}$ was derived from the histogram distribution, according to

$\mathrm{TEP}_{-\mathrm{micro}}=\frac{a}{12} \sum_{i} n_{i} r_{i}^{D}$

where $n_{i}$ is the concentration of TEP in the size class $i$ and $r_{i}$ the mean equivalent spherical radius of this size class. The constant, $a=0.25 \times 10^{-6} \mu \mathrm{gC}$, was determined by Mari (1999).

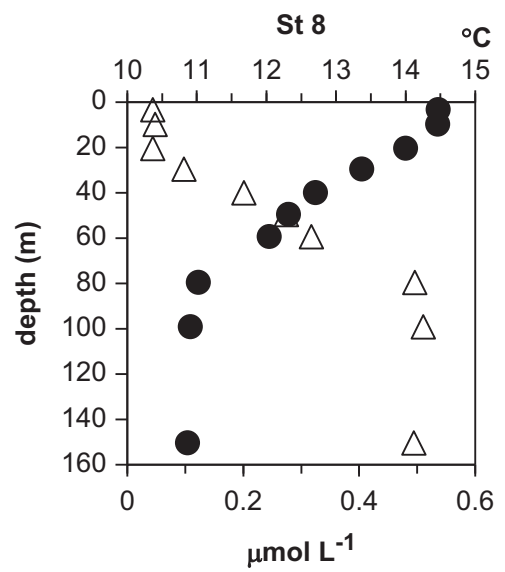

Temperature
St 7

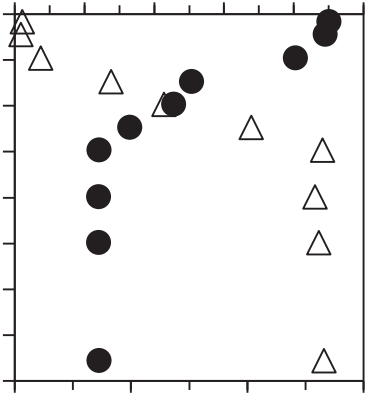

St 4(4bis)

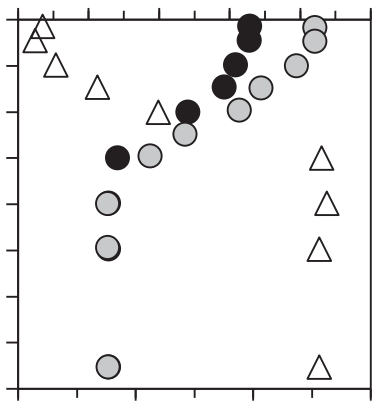

St 5

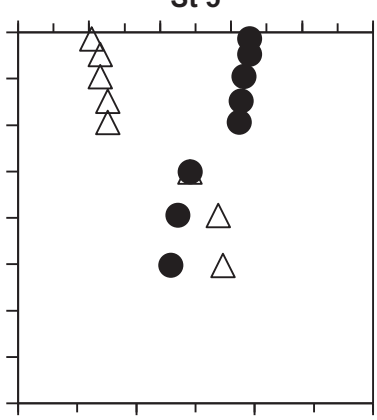

St 6

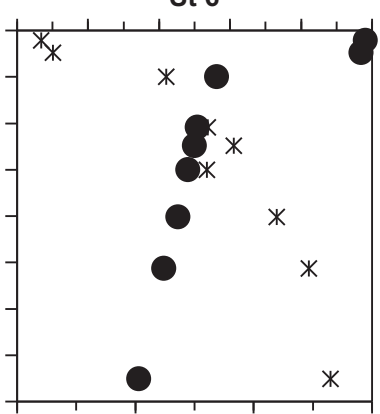

St 1(1bis)

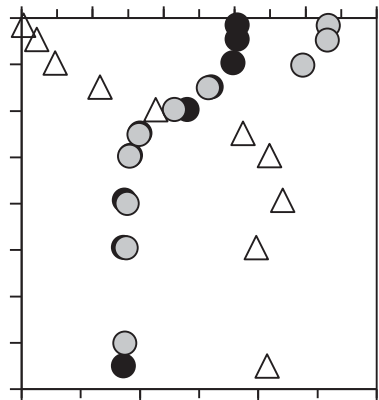

St 2

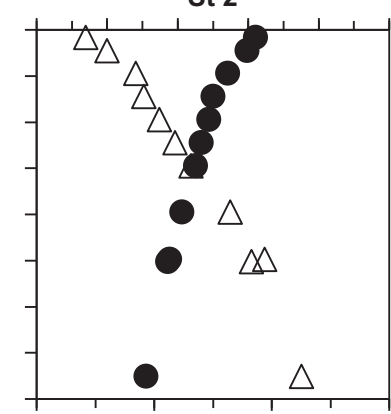

St 3

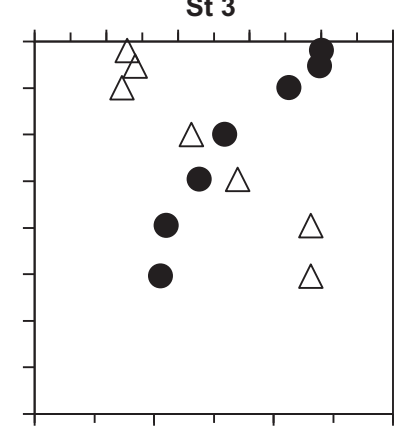

Fig. 2. Vertical profiles of temperature and phosphate concentration $\left(\mathrm{PO}_{4}\right)$ in the upper $160 \mathrm{~m}$ over the continental shelf (stations $1,1 \mathrm{bis}, 4,4 \mathrm{bis}, 7$ and 8 ) and over the slope (stations 2, 3, 5 and 6). Grey symbols represent the revisited stations; $\mathrm{PO}_{4}$ concentrations were similar at the revisited stations 1 bis and 4bis (superposed dots). For this figure and the following ones, the organization of the stations on the chart follows the geographic localization of the stations (stations 8, 7, 4 and 1 are located on the shelf and stations 5, 2,6 and 3 are located on the slope), as represented in the inner box showing station names and the bathymetry of the area. 


\section{Results}

\subsection{Hydrography}

Vertical distributions of temperature revealed that seasurface temperatures ranged between 13.0 and $14.0^{\circ} \mathrm{C}$ during the first leg (stations 1-5) and increased up to $14.9^{\circ} \mathrm{C}$ during the second leg (stations $6,7,8,4$ bis and 1bis) (Fig. 2). They also show that the upper water column over the continental shelf can be divided into 3 distinct parts: (i) a thin surface mixed layer of $10 \mathrm{~m}$, (ii) an intermediate layer displaying a strong vertical gradient and (iii) a homogeneous cold deep layer below $60 \mathrm{~m}\left(11.4^{\circ} \mathrm{C}\right)$.

The smaller temperature gradient on the continental slope suggests input of a cold, deeper water mass in the upper $25-35 \mathrm{~m}$, which corresponds to the photic zone (see below). This induced a mixing of the upper layer of the water column. Between the two legs, warming of the surface layer deepened the vertical temperature gradient down to $50 \mathrm{~m}$ depth at the stations 1 bis and 4bis. Salinity stayed within a narrow range of 35.5-35.6 down to $800 \mathrm{~m}$ depth at the deepest station 6 (data not shown).

Dissolved phosphate concentration was on average $0.49 \pm 0.04 \mu \mathrm{M}$ (average \pm standard deviation; $n=7$ ) at $150 \mathrm{~m}$ depth, while $\mathrm{PO}_{4}$ was depleted in surface waters (Fig. 2). Compared to the slope, the continental shelf was more $\mathrm{PO}_{4}$ depleted, and the concentrations in the upper $10 \mathrm{~m}$ ranged between 0.01 and $0.05 \mu \mathrm{M}$. Higher surface concentrations of phosphate were observed for the shelfbreak $(0.08-0.16 \mu \mathrm{M})$, where the surface layer only occasionally fell below $0.05 \mu \mathrm{M}$ (station 6) during the second leg (Fig. 2).

\subsection{Chlorophyll-a and reflectance}

Satellite images showed surface Chl- $a$ concentrations (Fig. 1a and c) and several HR patches (Fig. 1b and d) distributed inshore of the $200 \mathrm{~m}$ isobath, the bathymetric
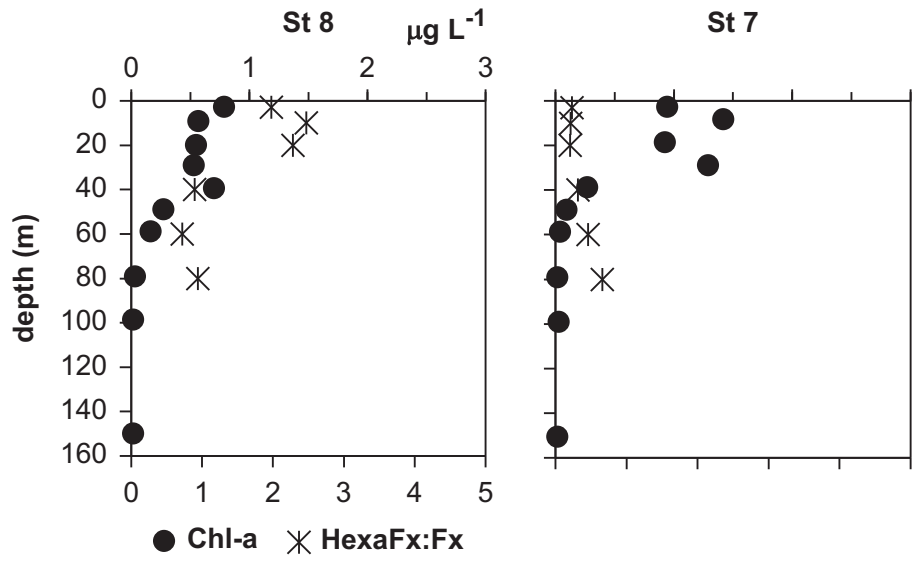

St 4(4bis)

St 1(1bis)
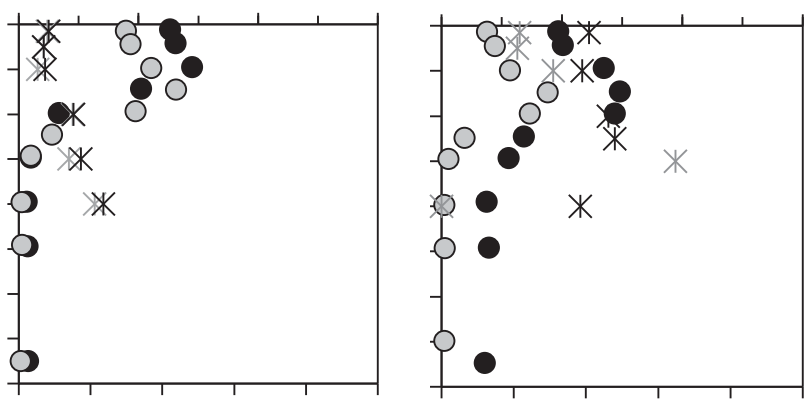

St 5

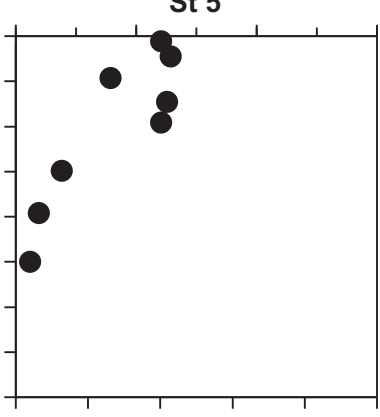

St 2
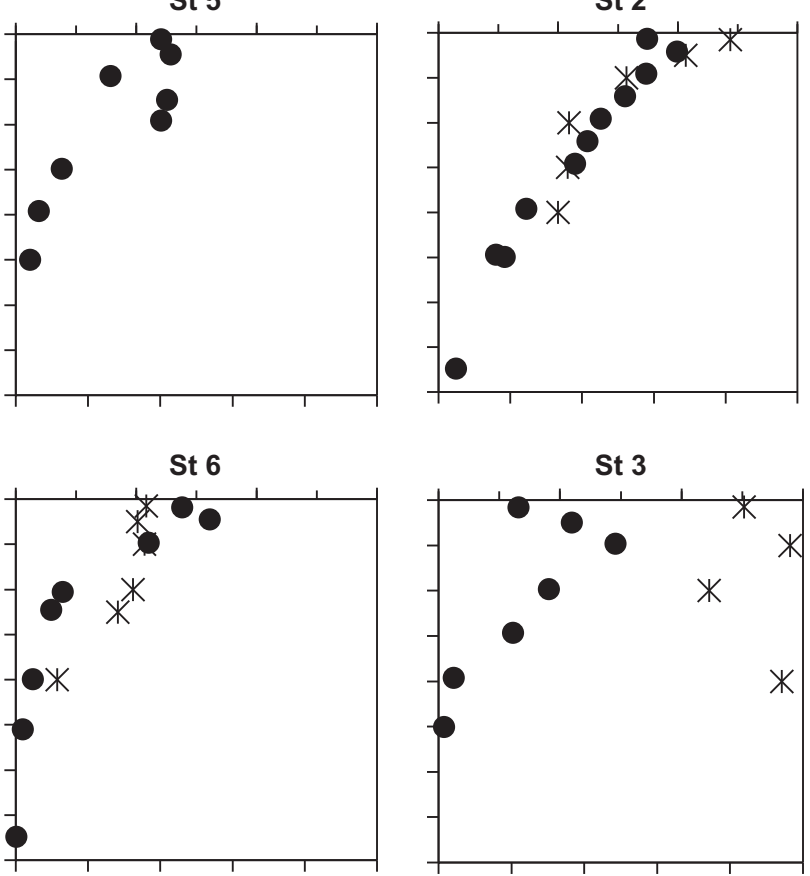

Fig. 3. Vertical profiles of chlorophyll- $a$ (Chl- $a$ ) concentration $\left(\mu \mathrm{g} \mathrm{L}^{-1}\right)$ (black dots) and relative contribution of the coccolithophorid biomass (crosses), as represented by the ratio of the diagnostic pigments for coccolithophores (19'-hexanoyloxyfucoxanthin, HexaFx) and diatoms (fucoxanthin, Fx) on the lower scale. Station 5 was not sampled for diagnostic pigments concentrations. Grey symbols represent the revisited stations ( $1 \mathrm{bis}$ and $4 \mathrm{bis}$ ). 
boundary between the open ocean and the continental shelf of the northern Bay of Biscay, in June 2006. The comparison of MODIS (Fig. 1a and c) and reflectance (Fig. 1b and d) images revealed changes in phytoplankton biomass in the southern HR patch (stations 4 , 7 and 8 ) between the two legs. An overall decline in surface Chl- $a$ concentration was observed between the two periods at the revisited stations. At stations 4 bis, 7 and 8 this decline was associated with an increase in reflectance.

Sea-surface Chl- $a$ concentration ranged between 0.5 and $2.0 \mu \mathrm{g} \mathrm{L}^{-1}$ (Fig. 3). The highest concentration was determined at station 2, where the concentration in the photic zone (ranging between 25 and $37 \mathrm{~m}$ depth based on light measurements) exceeded $1.5 \mu \mathrm{g} \mathrm{L}^{-1}$. The vertical profiles over the continental shelf showed higher Chl- $a$ concentration at intermediate depth situated between 20 and $40 \mathrm{~m}$, which decreased strongly down to $80 \mathrm{~m}$. At stations 1 bis and 4 bis, 9 days and 6 days, respectively, after the initial visit, Chl- $a$ concen- trations in surface waters decreased, respectively, by 0.6 and $0.2 \mu \mathrm{g} \mathrm{L}^{-1}$. As inferred from Chl- $a$ concentration and pigment composition (Fig. 3), the mixed phytoplankton community was dominated by coccolithophores at stations 1, 2 and 3.

\section{3. $P O C$}

The highest concentrations of POC were observed within the upper $20 \mathrm{~m}$ of the water column, ranging between 10 and $15 \mu \mathrm{M}$ and reaching up to $25 \mu \mathrm{M}$ at station 7 (Fig. 4). Concentrations were lower than $2.5 \mu \mathrm{M}$ below $20 \mathrm{~m}$ depth, except for station 1, where a concentration of $7.7 \mu \mathrm{M}$ was determined a few meters above the sea-bottom, which may be linked to resuspension of sediments. At station 4bis, POC concentration in the water column was significantly less than at other stations. No significant difference in POC concentration was observed between station 1 and 1 bis.

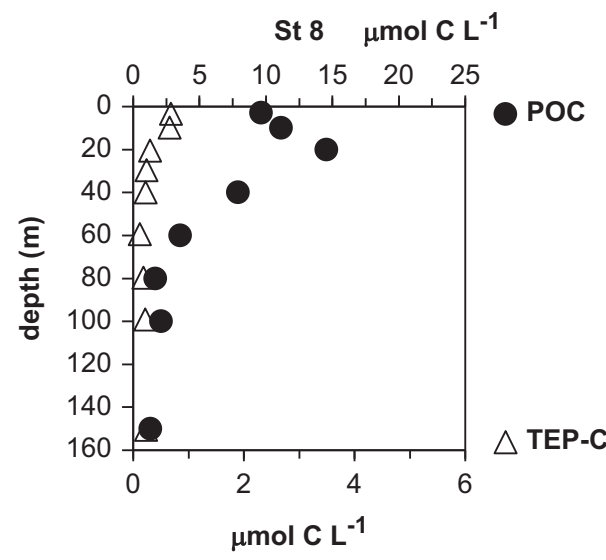

St 7

St 4(4bis)

St 1(1bis)
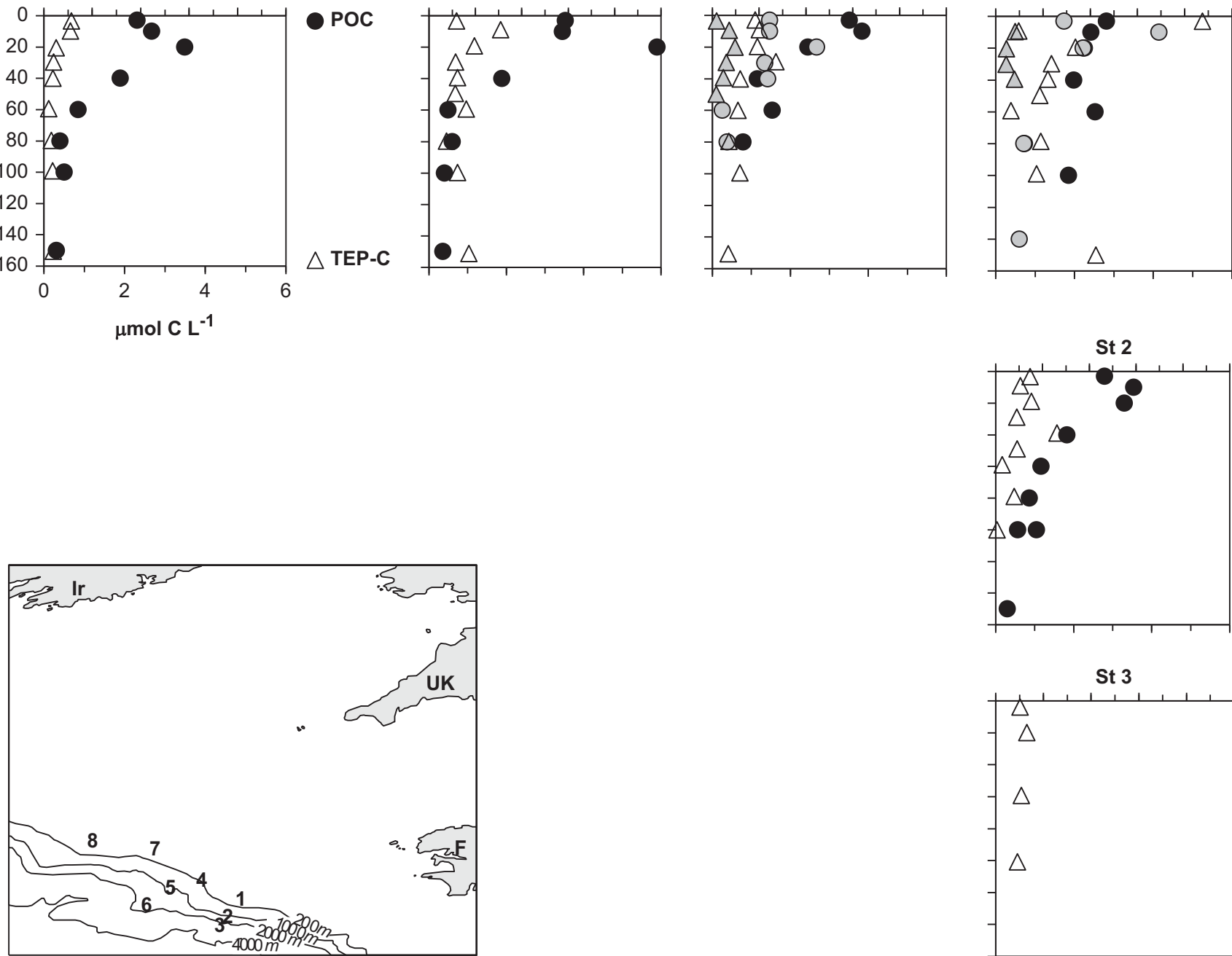

St 3

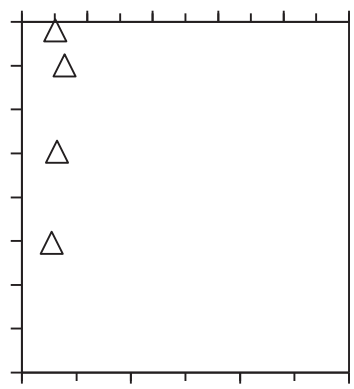

Fig. 4. Particulate organic carbon (POC) concentration ( $\mu$ mol $\mathrm{CL}^{-1}$ ) (black dots) and TEP- $\mathrm{C}_{\text {micro }}$ estimates $\left(\mu \mathrm{mol} \mathrm{CL}^{-1}\right.$ ). Grey symbols represent the revisited stations ( 1 bis and 4bis). Stations 3, 5 and 6 were not sampled for POC; stations 3 and 5 were not sampled for TEP-C. 


\subsection{Concentration and size distribution of TEP}

\subsubsection{TEP $P_{\text {color }}$}

The vertical profiles of relative $\mathrm{TEP}_{\text {color }}$ absorbance exhibited strong variations, achieving maximum values (100\%) in the surface or subsurface layer (Fig. 5). A general decrease of absorbance was observed from surface to depth, showing similar vertical distribution patterns as Chl- $a$ and POC. The lowest absorbance (normalised for $1 \mathrm{~L}$ of seawater) was observed in the deepest samples and ranged between $9 \%$ and $14.5 \%$ below $150 \mathrm{~m}$ (not shown). In contrast, the upper $40 \mathrm{~m}$ exhibited more variable values.

\subsubsection{Concentration and size distribution of TEP $P_{\text {micro }}$}

The microscopic determination of TEP allowed for their enumeration and classification into size classes, based on their equivalent spherical diameter (ESD). The size frequency distribution of TEP showed a dominance
(>90\%) of particles smaller than $20 \mu \mathrm{m}$ (ESD) in surface waters. Fig. 6 is a three-dimensional representation of the vertical distribution of $\mathrm{TEP}_{\text {micro }}$ volume concentration (in $\mu \mathrm{m}^{3} \mathrm{~mL}^{-1} \mu \mathrm{m}^{-1}$ ) as a function of the size of particles in the water column. The larger particles ranged between 20 and $30 \mu \mathrm{m}$ and were abundant in the upper part of the water column. Their concentration strongly decreased with depth to become insignificant below $80 \mathrm{~m}$. The coincidence of abundant large and small particles in the first $30 \mathrm{~m}$ (i.e. the upper mixed layer) can be considered as the result of the assembly of lager particles from smaller ones by aggregation. Therefore, the snapshot of this station 8 likely represents the different steps of the formation of TEP from their small precursors, formed by coagulation of phytoplankton exudates, to larger particles formed by the aggregation of the bulk colloidal material.

In accordance with the distribution of TEP color, $\mathrm{TEP}_{\text {micro }}$ abundance was higher in surface waters, down to $40 \mathrm{~m}$ depth, ranging between $2.1 \times 10^{3} \mathrm{~mL}^{-1}$ and $43.7 \times 10^{3}$ $\mathrm{mL}^{-1}$ at stations 2 and 1 , respectively (Fig. 7). At greater

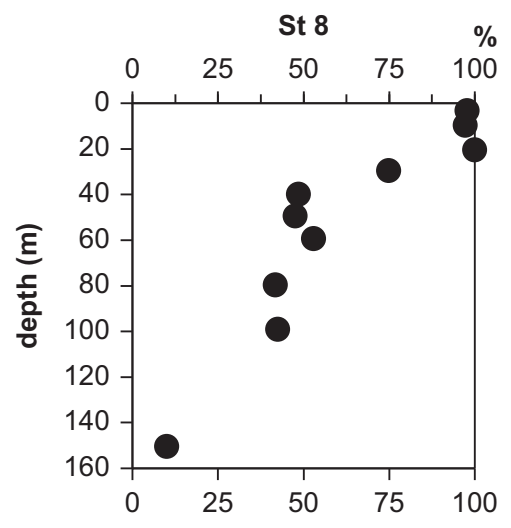

St 7

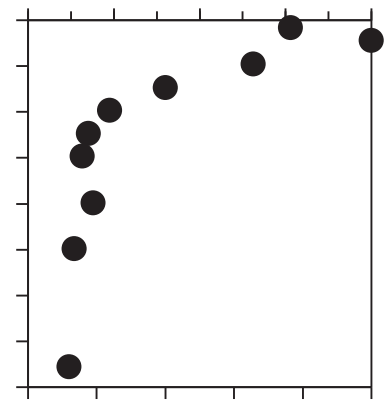

St 4(4bis)

St 1(1bis)
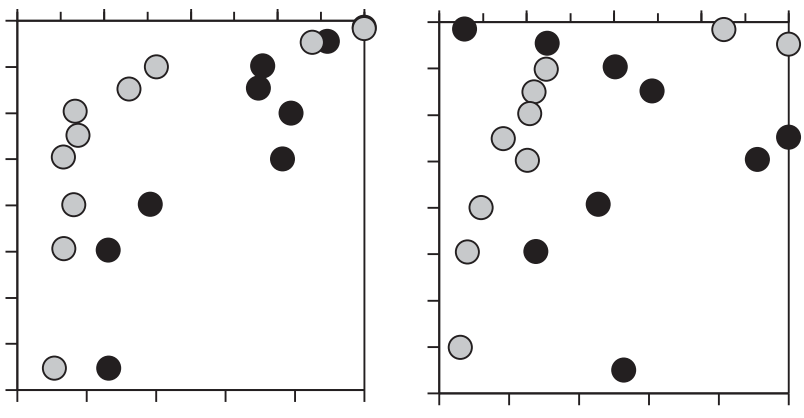

TEP \%abs
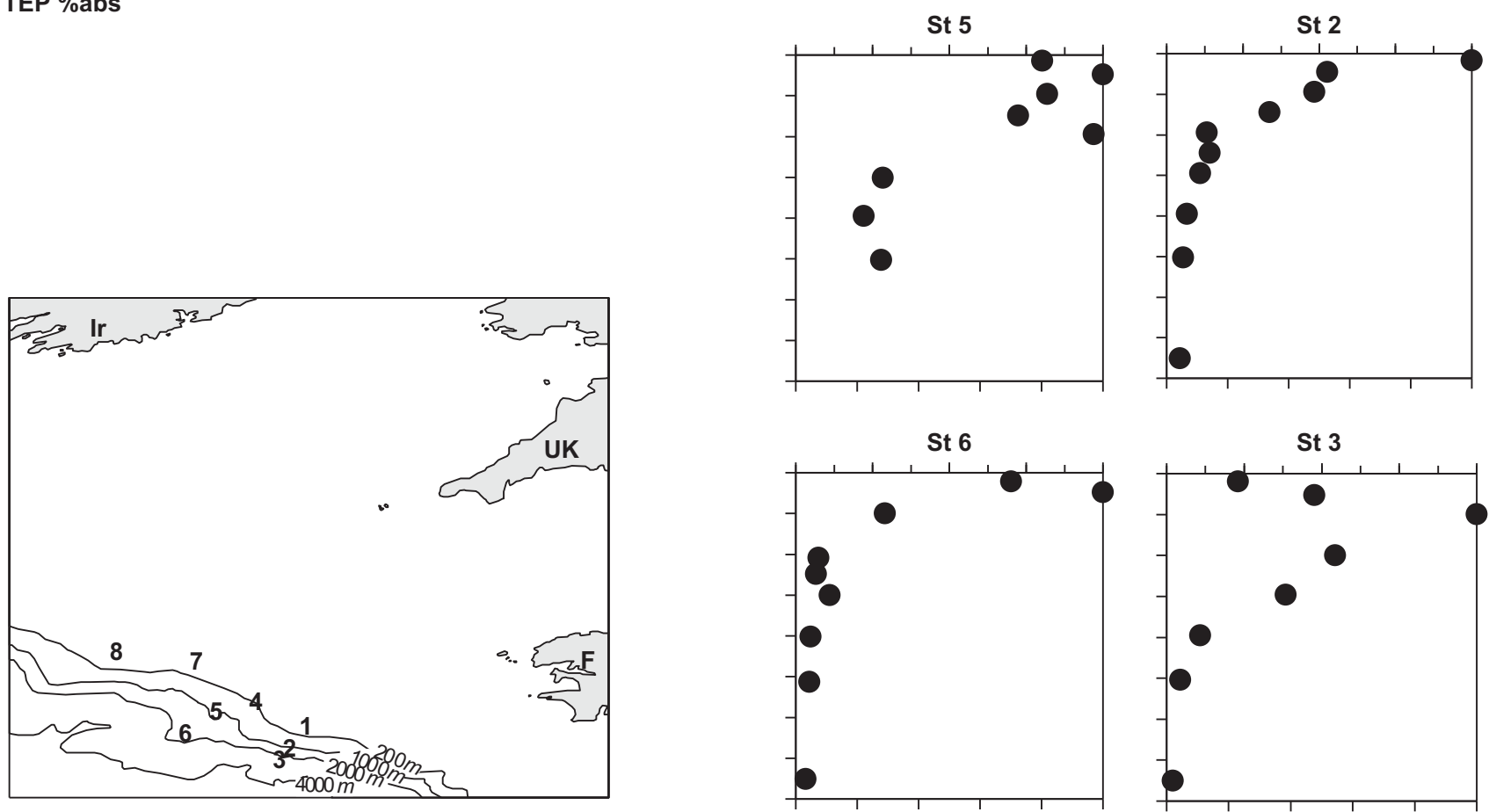

Fig. 5. TEP $\mathrm{P}_{\text {color }}$ expressed in \% of relative absorbance compared to the maximum absorbance obtained for each station. Grey symbols represent the values at the revisited stations $4 \mathrm{bis}$ and $1 \mathrm{bis}$. 


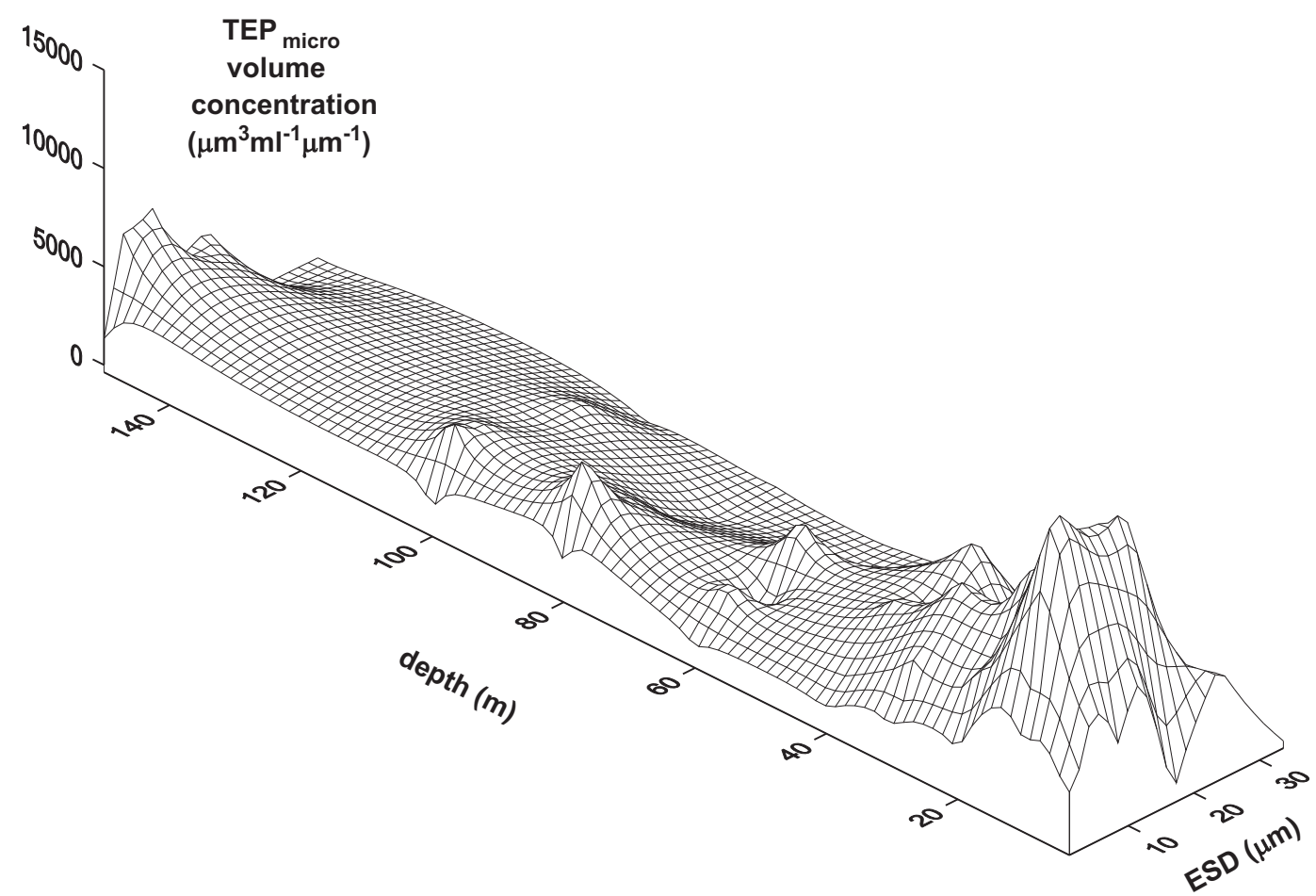

Fig. 6. Variation with depth (m) of TEP micro volume concentration $\left(\mu \mathrm{m}^{3} \mathrm{~mL}^{-1} \mu \mathrm{m}^{-1}\right.$ ) per size class (equivalent spherical diameter (ESD) in $\left.\mu \mathrm{m}\right)$ at station 8 . The volume concentration was calculated on the assumption of spherical particles and represents the mean volume of the particles in a given size class in $1 \mathrm{~mL}$ of the sample.

depth the distribution was relatively uniform and in the lower range of surface abundances. In the HR patch (stations 4, 7 and 8), TEP micro $_{\text {exhibited concentrations in }}$ the range of $3.3 \times 10^{3} \mathrm{~mL}^{-1}$ to $20.2 \times 10^{3} \mathrm{~mL}^{-1}$. An overall 2-fold increase of $\mathrm{TEP}_{\text {micro, }}$ in association with a decrease of Chl- $a$ concentration after 6 days, was observed at the revisited stations $4 \mathrm{bis}$, where concentrations ranged between $6.7 \times 10^{3} \mathrm{~mL}^{-1}$ and $20.2 \times 10^{3} \mathrm{~mL}^{-1}$. However, such an increase in TEP concentration was not observed after 9 days at stations 1 and 1bis, despite a similar decrease of Chl-a concentration.

A power-law relationship fitted the size distributions of TEP very well in all cases $\left(r^{2}>0.9\right)$ as shown in Fig. 8 . The size distribution can be described by spectral slope, $\delta$, with less negative values indicating an increase with the fraction of large particles and, potentially, TEP aggregation. In the top $40 \mathrm{~m}, \delta$ values ranged between -3 and -2 (Fig. 9). The increase of $\delta$ in the surface layer at the revisited station 1 bis suggests that aggregation of TEP had taken place after an elapsed time of 9 days. In contrast, a decrease of $\delta$ was observed between station 4 and 4 bis. Together with an increase of total TEP abundance, this could be attributed to the production of smaller TEP. The fractal dimension, $D$, of TEP was deduced from $\delta$, and ranged between 2.51 and 2.56 .

\subsubsection{TEP-C estimates}

Surface concentration of TEP- $\mathrm{C}_{\text {micro }}$ ranged between 0.44 and $5.25 \mu \mathrm{mol} \mathrm{C} \mathrm{L}^{-1}$ at stations 4 bis and 1 , showing higher concentrations above the thermocline (Fig. 4). Except for station 1, TEP- $\mathrm{C}_{\text {micro }}$ concentrations in the photic zone were found to be below $2.00 \mu \mathrm{molCL}^{-1}$. At greater depths, $0.75 \mu \mathrm{mol} \mathrm{C} \mathrm{L}{ }^{-1}$ was an upper limit for TEP- $C_{\text {micro }}$ at all stations, except station 1 , where the resuspension of sediment was probably responsible for higher TEP-C estimates close to the bottom. Low variability in TEP-C was observed at the revisited stations (1bis and 4bis).

\section{Discussion}

\subsection{Relationship between bloom development and biological parameters}

Based on remote sensing images (Fig. 1) and vertical profiles of nutrients (Fig. 2) and Chl- $a$ (Fig. 3), the coccolithophorid bloom investigated in our study can be split into two distinctive regions: (i) a southern part associated with higher Chl- $a$ and lower reflectance, where coccolithophores were in the initial stage of the bloom (stations 1, 2, 3 and 6) and (ii) a northern part where increased reflectance rather suggested that the coccolithophorid bloom had reached a stationary phase (stations 4, 5, 7 and 8).

The surface waters of the study area were characterized by the formation of a seasonal thermocline at $50 \mathrm{~m}$ depth on the continental shelf and a general warming by $1{ }^{\circ} \mathrm{C}$ during the course of the cruise (10 days). Over the shelf-break (stations 2, 3 and 5), the temperature below the thermocline decreased continuously with depth, suggesting the mixing of the upper layer with a deep 


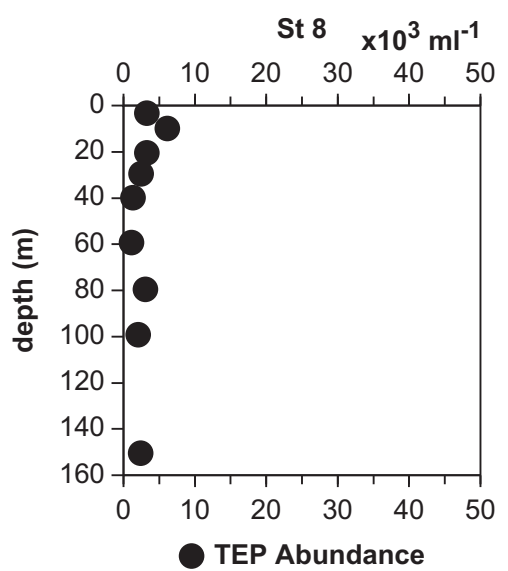

St 7

St 4(4bis)

St 1 (1bis)
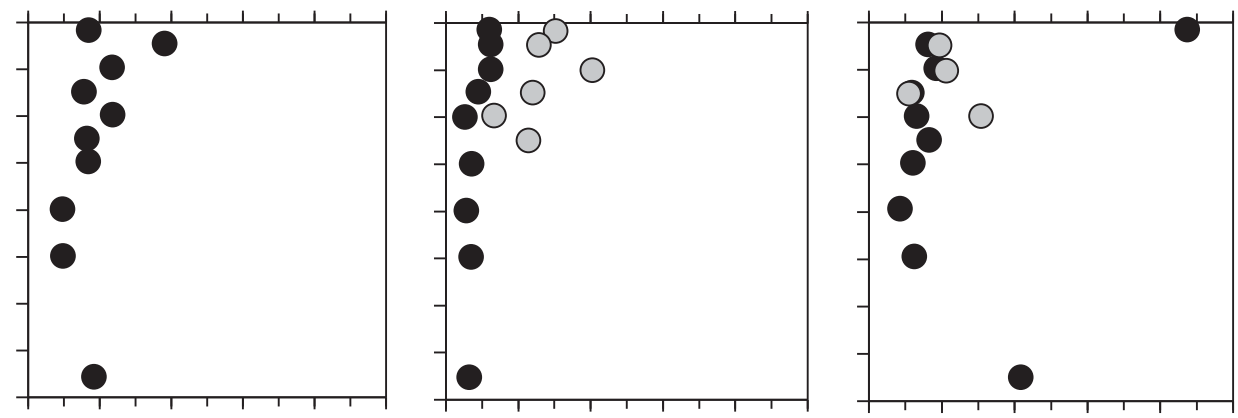

St 2
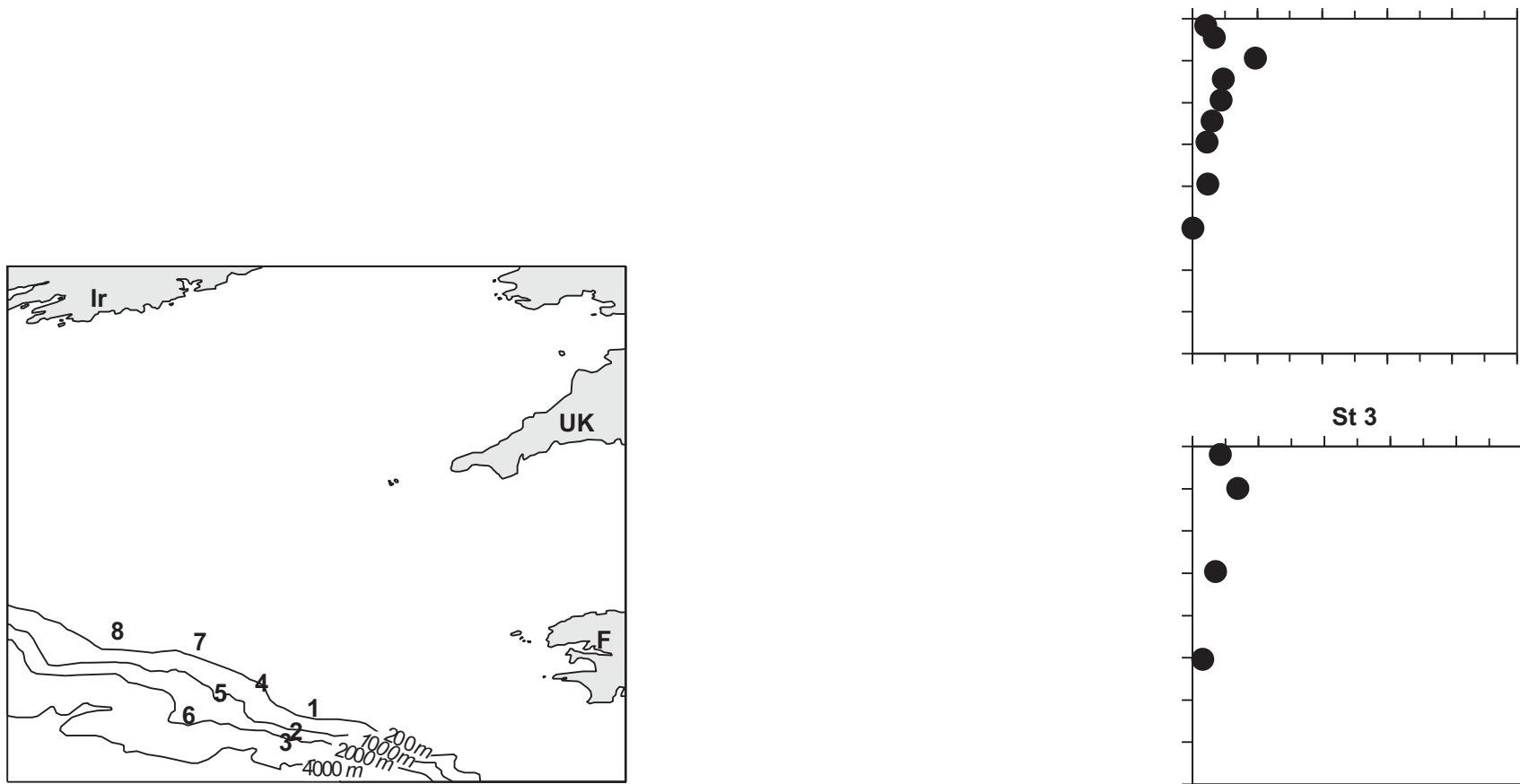

St 3

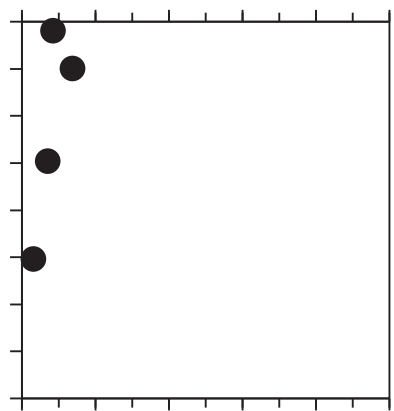

Fig. 7. Abundance of $\operatorname{TEP}_{\text {micro }}\left(\times 10^{3} \mathrm{~mL}^{-1}\right)$ of seawater. Stations 5 and 6 were not sampled for this parameter. Grey symbols represent the values at the revisited stations 4 bis and 1 bis.

cold nutrient-rich water mass. A significant $\left(r^{2}=0.82\right.$, $n=96, p<0.0001$ ) correlation was observed between phosphate consumption and temperature, indicating a strong control of hydrodynamics on phytoplankton activity (Wollast and Chou, 2001). The northern Bay of Biscay is characterized by intermittent inputs of nutrient-rich deep water to the photic layer promoted by internal waves (Huthnance et al., 2001), enhancing and sustaining localized biological activity in spring (Joint et al., 2001). In the Bay of Biscay, two diatom blooms usually occur during phytoplankton succession in spring and fall, but diatoms remain in the phytoplanktonic community during the spring bloom (Joint et al., 2001). Prymnesiophytes, to which coccolithophores belong, are an important component of the phytoplankton community in this area, especially in spring, and persist at low densities over the whole annual cycle (Joint et al., 2001). The accumulation of coccoliths, the minute calcite discs produced by this species, modifies the optical properties of surface seawater leading to high reflectance so that high reflectances are traditionally associated with coccolithophorid blooms (Balch et al., 1996). The spatial distribution of localized HR patches on satellite images (Fig. 1b and d) suggested the development of a coccolithophore-dominated bloom during our study, as reported by Holligan et al. (1983, 1993a, 1993b), the GREPMA (1988), and Brown and Yoder (1994) in the North Atlantic. The most common species that is known to produce such important blooms is E. huxleyi (Brown and Yoder, 1994).

Surface distributions of Chl- $a$ and $\mathrm{PO}_{4}$ suggest that phytoplankton production has led to inorganic phosphate depletion in surface waters. Dissolved silicates (data not shown) remained below $2 \mu \mathrm{M}$ in surface waters, probably because of the uptake of this nutrient by diatoms (Egge and Aksnes, 1992). Such a situation likely triggers coccolithophores at the period of high irradiance (Tyrrell and Merico, 2004), whose requirements for inorganic phosphorus are relatively low, because their reliance on alkaline phosphatase allows them to use organic phosphorus (Riegman et al., 2000). 


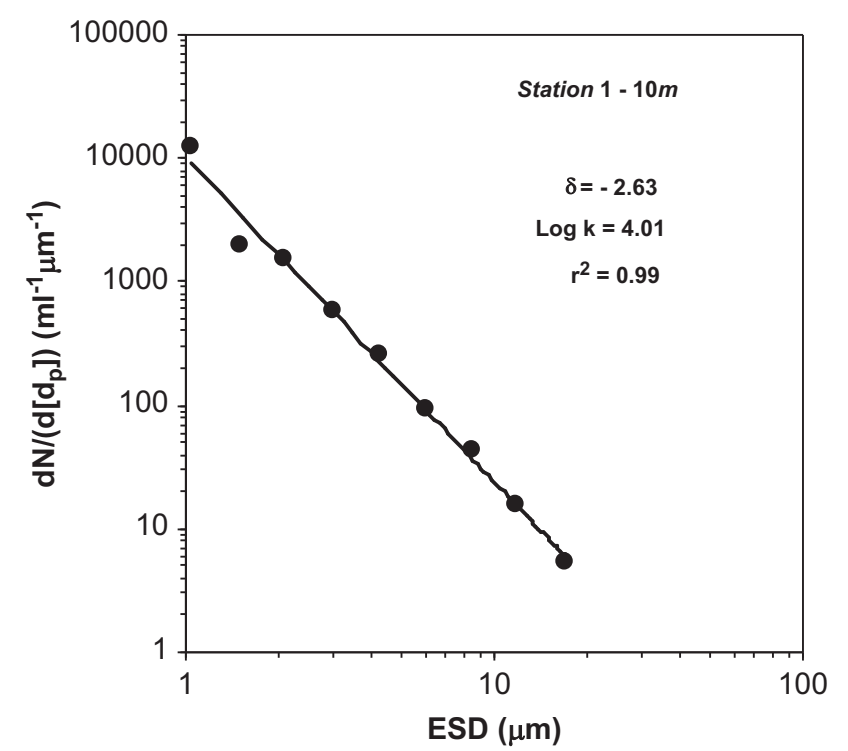

Fig. 8. Differential TEP size distribution at Station $1(10 \mathrm{~m})$ and the spectral slope $(\delta)$ fitted to the data by a linear regression $\left(r^{2}=0.99\right)$ over the size spectrum of particles represented by the mean equivalent spherical diameter in the size class (ESD in $\mu \mathrm{m}$ ). The $Y$-intercept of the regression line corresponds to $\log k$.

\subsection{TEP concentrations observed in the field}

Microscopic enumeration and sizing of TEP $\mathrm{Picro}_{\text {mic }}$ (Table 1) showed abundant $\left(6.13 \times 10^{3} \mathrm{~mL}^{-1}\right.$ to $4.4 \times 10^{4}$ $\left.\mathrm{mL}^{-1}\right)$, relatively small $(0.5-20 \mu \mathrm{m}$ ESD) particles leading to a low total volume concentration of TEP (0.05-2.2 ppm) (not shown). The fractal scaling of TEP $(D)$, deduced from the spectral slope (Eq. (1)), was close to the value of 2.55 proposed by Mari and Burd (1998) for naturally occurring TEP. These concentrations agreed with previous estimates (0.76-4.1 ppm) in the NE Atlantic mixed layer (Engel, 2004) and were in the lower range (3-310 ppm) of earlier observations in a coastal diatom bloom of the Baltic Sea (Mari and Burd, 1998). Small variations of the spectral slope $(\delta)$ with depth and between stations suggest only minor changes in the size distribution of particles. Hence, TEP aggregation can hardly be assessed from size distributions in this study. Together with the observed increase in total $\mathrm{TEP}_{\text {micro }}$ abundance at revisited stations, the dominance of small particles may point towards TEP production at the time of our study, rather than to massive aggregation, which may occur in later phases of phytoplankton blooms. Concentrations of $\mathrm{TEP}_{\text {color }}$ in coastal regions range from $<100$ to $3000 \mu \mathrm{g} \mathrm{Xeq} \mathrm{L}{ }^{-1}$ (Passow, 2002). For an open ocean transect in the NE Atlantic surface water $\mathrm{TEP}_{\text {color }}$ concentration ranged from 40 to $120 \mu \mathrm{g} \mathrm{Xeq} \mathrm{L}^{-1}$ in the top $20 \mathrm{~m}$ (Engel, 2004), and vertical patterns of TEP distribution were similar to those reported in Fig. 5. The upper and lower boundaries of TEP-C concentration provided by Engel (2004) lead to estimates between 30 and $89 \mu \mathrm{gCL}^{-1}$ and are thus in agreement with our values determined by TEP- $C_{\text {micro }}$ (Fig. 4). Previous measurements conducted in the study area in June 2004 revealed $\mathrm{TEP}_{\text {color }}$ concentrations similar to those determined by Engel (2004) (up to $120 \mu \mathrm{g} \mathrm{Xeq} \mathrm{L}^{-1}$ ) and averaged TEP- $\mathrm{C}_{\text {color }}$ was $29.0 \pm 4.2 \mu \mathrm{gCL}^{-1}$ (mean \pm confidence interval at $95 \%, n=54$ ) in the surface layer (Harlay et al., in prep.).

TEP- $C_{\text {micro }}$ concentrations above $20 \mu \mathrm{g} \mathrm{CL}^{-1}$ were determined in samples exhibiting various degrees of coccolithophorid dominance, based on the HexaFx:Fx ratio of diagnostic pigments (Fig. 3). At stations 2 and 3, where HexaFx:Fx ratio was high, TEP- $\mathrm{C}_{\text {micro }}$ did not exceed $10 \mu \mathrm{g} \mathrm{CL}^{-1}$. Hence, no particular trend in relation with TEP- $C_{\text {micro }}$ estimates in the phytoplankton assemblage could be assessed from coccolithophorid dominance at the time of our survey. We hypothesize that the history of water masses in terms of phytoplankton activity and the taxonomic composition of phytoplankton assemblages in the different patches investigated are responsible for this pattern.

\subsection{Contribution of TEP-C to POC}

The relative contribution of the TEP-C to POC was estimated for each depth by the molar ratio of TEP- $C_{\text {micro }}$ to POC in the water column that ranged between $1.5 \%$ and $68 \%$. TEP- $\mathrm{C}_{\text {micro }}$ accounted for $12 \%$ of POC in the photic zone and was slightly lower than our estimate for the photic zone in the same area during an earlier cruise to this study site (June 2004), where $26 \pm 4 \%$ was observed

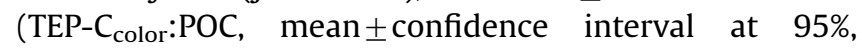
$n=31$ ) (Harlay et al., in prep.). The contribution of TEP-C to POC during this coccolithophorid bloom is in the range reported in previous studies, which indicated a contribution of TEP-C to POC ranging between $17 \%$ and 54\% (Mari, 1999; Engel and Passow, 2001; Engel, 2002). Statistically, no significant changes were detected after 9 days at station 1 .

\subsection{TEP production and carbon cycling}

The decoupling from inorganic nutrient of carbon production by carbon over-consumption (Engel et al., 2002; Schartau et al., 2007) suggests that the flux of particulate carbon might be enhanced when TEP is produced, rendering coccolithophores good candidates for the export and sequestration of carbon. Several studies have shown that the balance between TEP and solid particles, such as cells, co-determines the efficiency of particle coagulation and formation of macroscopic aggregates (Logan et al., 1995; Engel, 2000; Kahl et al., 2008). Particle aggregates are a major vehicle for organic matter export to the deep ocean. Coccolithophores potentially enhance the efficiency of organic matter export through the addition of mineral ballast (François et al., 2002; Klaas and Archer, 2002). Hence, TEP production during coccolithophorid blooms may control aggregate formation and enhance organic matter export (De la Rocha and Passow, 2007). The deposition of gelatinous detritus mixed with E. huxleyi at the seafloor has been described by Cadée (1985) for the North Sea. Based on the sinking velocity of coccoliths and coccospheres, Holligan et al. (1993b) estimated the time required for the coccolithophore optical signature to disappear from satellite images to be 

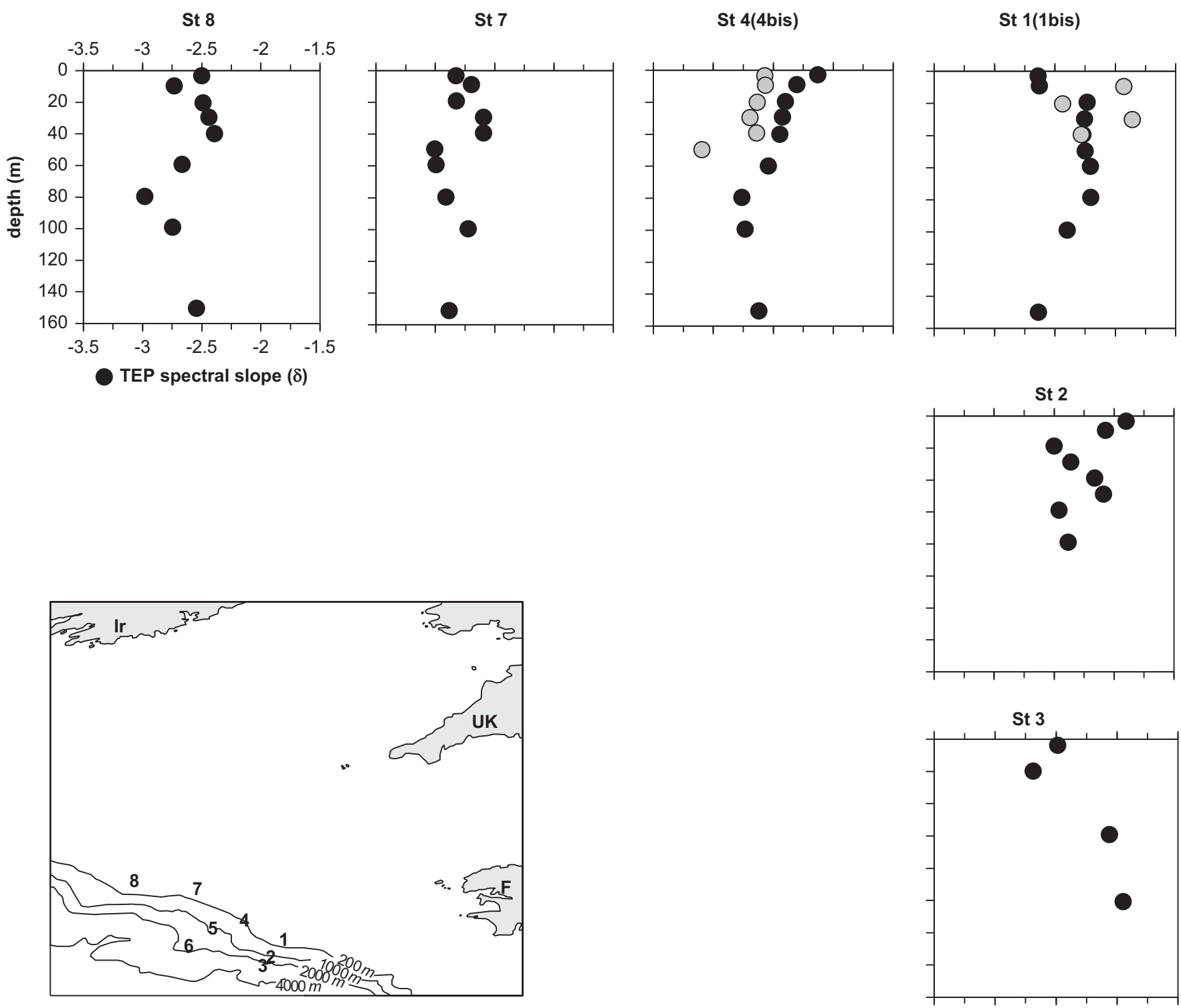

Fig. 9. Spectral slope $(\delta)$ of the TEP micro size distributions. An increase of $\delta$ corresponds to an increase of the fraction of large TEP ${ }_{\text {micro }}$ Grey symbols represent the values at the revisited stations 4 bis and 1 bis. Stations 5 and 6 were not sampled for this parameter.

$>200 \mathrm{~d}$ in the North Sea. However, the effective life-time of coccolithophorid blooms does not exceed $40 \mathrm{~d}$ after the optical signature appears (Holligan et al., 1993b). The persistence of coccolithophores in waters depleted in nutrients for 3-6 weeks and the potential production of up to 400 coccoliths per cell with a mean delay of $2-3 \mathrm{~h}$ per coccolith (Linschooten et al., 1991; Fernández et al., 1993) suggest that cells remain active for several weeks after the onset of the bloom. If carbon over-consumption can be applied to coccolithophorid physiology, one can suspect that the significance of coccolithophores in carbon cycling, at least of the bloom-forming species E. huxleyi, has been under-estimated. The E. huxleyi blooms could result in massive aggregation events that wash out the surface waters from detritus and particles.

Our survey probably did not cover any massive aggregation phase of the coccolithophorid bloom because of the small size of TEP. Therefore, the contribution of TEP in coccolithophore aggregates to the vertical export was not quantified in this study. However, the deposition of gelatinous detritus over the continental slope of the Bay of Biscay has been found to occur later in the summer (de Wilde et al., 1998: McCave et al., 2001). Pigment analysis and scanning electron microscopy of particulate samples in late August 1995 showed that coccolithophores were the major contributors to this mass deposition (de Wilde et al., 1998). The carbon content of the deposited mucus layer represented $250 \mathrm{mmol} \mathrm{C} \mathrm{m}^{-2}$ and covered an area of $50000 \mathrm{~km}^{2}$ (de Wilde et al., 1998), comparable to the $65000 \mathrm{~km}^{2}$ surface area of a coccolithophorid bloom at the continental margin of the Gulf of Biscay observed in June 2006. Since specific pigments are well preserved together with the carbonates, this detrital mass deposition indicates a tight coupling of particulate matter export and surface production of coccolithophores. The production of TEP observed during the present study could 
constitute the first step within the process of coccolithophore aggregation, sedimentation and seafloor deposition in the Bay of Biscay.

\section{Conclusions}

The present study shows agreement between the vertical distribution of TEP determined with the microscopic (this study) and the colorimetric (Engel, 2004; Harlay et al., in prep.) approaches. The estimates of TEP-C obtained with the microscopic approach are comparable to those previously obtained with the colorimetric one in the Bay of Biscay (coccolithophorid bloom in June 2004, Harlay et al., in prep.) and during an offshore transect at the same latitude in the NE Atlantic Ocean (Engel, 2004). High absorbance of particles issued from the area where coccolithophores occurred, or had occurred in the past history of the water mass, has been pointed out. We suggest that during coccolithophorid blooms, the production of TEP is also occurring, as already determined for other phytoplankton groups (Passow, 2002) as a possible consequence of carbon over-consumption by this taxon. The implication of those particles for the seasonal cycling of carbon is enhanced by the physical properties of the water column. The formation of aggregates potentially contributes, through the ballast of aggregates with biogenic calcite, to efficient and rapid export of carbon out of the photic layer and important deposition over the seafloor. Carbon over-consumption by phytoplankton and the subsequent transformation of the cellular releases into TEP (Schartau et al., 2007) account for an additional sink for carbon sequestration in coccolithophorid blooms, where the efficiency of the carbon pump may not be limited to the production of biomass, as computed from variations in Chl- $a$ concentration (e.g. Iglesias-Rodriguez et al., 2002). However, such a mechanism has been neglected in carbon inventories because of the complexity of the study of gel phases in marine environments. The significance of gel particles in the global carbon cycle may have been under-estimated, so far, and improvement in the description of these processes is required to better constrain this flux as well as the development of techniques to estimate the coupling between the surface and the seafloor.

Further effort is then needed to increase the reproducibility of both approaches for estimating TEP-C. The microscopic approach, less sensitive to coccolithophorid density and changes in TEP stainability, provided a reliable estimate of the carbon content of TEP during this study. However, its use as a routine method for TEP determination during multidisciplinary studies is often discarded in favour of the colorimetric technique, which requires less labor and expertise. However, highly coloured TEP do not necessarily reflect high TEP-C (TEP- $\mathrm{C}_{\text {micro }}$ :POC of $\left.12 \%\right)$ but suggest different chemical properties of their constituents. Improvement of the methods is a particular challenge for studying possible changes in polysaccharide composition of TEP in aging-bloom situations (polysaccharide diagenesis) or for directly determining TEP-C in the field, since conversion factors obtained from phytoplankton blooms can only give rough estimates in peculiar conditions.

\section{Acknowledgements}

The authors would like to thank the officers and crewmembers of the R.V. Belgica for their logistic support onboard the ship during the survey conducted in the northern Bay of Biscay. Joan Backers, Jean-Pierre De Blauw and Gregory Deschepper of the Unit of the North Sea Mathematical Models (Brussels/Oostende, Belgium) are acknowledged for their support in data acquisition during the cruise. This study was financed by the Belgian Federal Science Policy Office in the framework of the PEACE project (Contract no. SD/CS/03A/B) and by the Helmholtz Association (Contract no. HZ-NG-102). C. De Bodt was supported by a Ph.D. grant from the EU FP6 IP CarboOcean project (Contract no. 511176-2). N. Van Oostende received a Ph.D. grant from the Institute for the Promotion of Innovation through Science and Technology in Flanders (IWT-Vlaanderen). This is also a contribution to the EU FP6 European Network of Excellence EUR-OCEANS (Contract no. 511106-2) and a Belgian input to the SOLAS international research initiative.

\section{References}

Alldredge, A.L., Passow, U., Logan, B.E., 1993. The abundance and significance of a class of large, transparent organic particles in the ocean. Deep Sea Research Part I: Oceanographic Research Papers 40, 1131-1140.

Arruda Fatibello, S.H.S., Henriques Vieira, A.A., Fatibello-Filho, O., 2004. A rapid spectrophotometric method for the determination of transparent exopolymer particles (TEP) in freshwater. Talanta 62, 81-85.

Balch, W.M., Kilpatrick, K.A., Holligan, P., Harbour, D., Fernandez, E., 1996. The 1991 coccolithophore bloom in the central North Atlantic.2. Relating optics to coccolith concentration. Limnology and Oceanography 41, 1684-1696.

Barlow, R.G., Mantoura, R.F.C., Cummings, D.G., Pond, D.W., Harris, R.P., 1998. Evolution of phytoplankton pigments in mesocosm experiments. Estuarine, Coastal and Shelf Science 46, 15-22.

Barlow, R.G., Mantoura, R.F.C., Gough, M.A., Fileman, T.W., 1993. Pigment signatures of the phytoplankton composition in the northeastern Atlantic during the 1990 spring bloom. Deep Sea Research Part II: Topical Studies in Oceanography 40, 459-477.

Berman, T., Viner-Mozzini, Y., 2001. Abundance and characteristics of polysaccharide and proteinaceous particles in Lake Kinneret. Aquatic Microbial Ecology 24, 255-264.

Brown, C.W., Yoder, J.A., 1994. Coccolithophorid blooms in the global ocean. Journal of Geophysical Research 99, 7467-7482.

Brussaard, C.P.D., Kuipers, B., Veldhuis, M.J.W., 2005. A mesocosm study of Phaeocystis globosa population dynamics: I. Regulatory role of viruses in bloom control. Harmful Algae 4, 859-874.

Cadée, G.C., 1985. Macroaggregates of Emiliana huxleyi in sediment traps. Marine Ecology-Progress Series 24, 193-196.

Catsberg, T., Larsen, A., Sandaa, R.A., Brussaard, C.P.D., Egge, J.K., Heldal, M., Thyrhaug, R., van Hannen, E.J., Bratbak, G., 2001. Microbial population dynamics and diversity during a bloom of the marine coccolithophorid Emiliania huxleyi (Haptophyta). Marine EcologyProgress Series 221, 39-43.

De La Rocha, C.L., Passow, U., 2007. Factors influencing the sinking of POC and the efficiency of the biological carbon pump. Deep Sea Research Part II: Topical Studies in Oceanography 54, 639-658.

de Wilde, P.A.W.J., Duineveld, G.C.A., Berghuis, E.M., Lavaleye, M.S.S., Kok, A., 1998. Late-summer mass deposition of gelatinous phytodetritus along the slope of the N.W. European Continental Margin. Progress in Oceanography 42, 165-187.

Delille, B., Harlay, J., Zondervan, I., Jacquet, S., Chou, L., Wollast, R., Bellerby, R.G.J., Frankignoulle, M., Borges, A.V., Riebesell, U., Gattuso, J.-P., 2005. Response of primary production and calcification to 
changes of $\mathrm{pCO}_{2}$ during experimental blooms of the coccolithophorid Emiliania huxleyi. Global Biogeochemical Cycles 19, GB2023.

Egge, J.K., Aksnes, D.L., 1992. Silica as regulating nutrient in phytoplankton competition. Marine Ecology-Progress Series 83, 281-289.

Engel, A., 2000. The role of transparent exopolymer particles (TEP) in the increase in apparent particle stickiness $(\alpha)$ during the decline of a diatom bloom. Journal of Plankton Research 22, 485-497.

Engel, A., 2002. Direct relationship between $\mathrm{CO}_{2}$ uptake and transparent exopolymer particles production in natural phytoplankton. Journal of Plankton Research 24, 49-53.

Engel, A., 2004. Distribution of transparent exopolymer particles (TEP) in the northeast Atlantic Ocean and their potential significance for aggregation processes. Deep Sea Research Part I: Oceanographic Research Papers 51, 83-92.

Engel, A., 2009. In: Wurl, O. (Ed.), Marine Gel Particles, Practical Guidelines for the Analysis of Seawater. CRC Press, Taylor \& Francis Group, Boca Rayton, FL, USA, in press. ISBN: 9781420073065.

Engel, A., Delille, B., Jacquet, S., Riebesell, U., Rochelle-Newall, E., Terbruggen, A., Zondervan, I., 2004. Transparent exopolymer particles and dissolved organic carbon production by Emiliania huxleyi exposed to different $\mathrm{CO}_{2}$ concentrations: a mesocosm experiment. Aquatic Microbial Ecology 34, 93-104.

Engel, A., Goldthwait, S., Passow, U., Alldredge, A.L., 2002. Temporal decoupling of carbon and nitrogen dynamics in a mesocosm diatom bloom. Limnology and Oceanography 47, 753-761.

Engel, A., Passow, U., 2001. Carbon and nitrogen content of transparent exopolymer particles (TEP) in relation to their Alcian Blue adsorption. Marine Ecology-Progress Series 219, 1-10.

Engel, A., Zondervan, I., Aerts, K., Benthien, A., Chou, L., DeLille, B., Gattuso, J.-P., Harlay, J., Heemann, C., Hoffmann, L., Jacquet, S., Nejstgaard, J., Pizay, M.-D., Rochelle-Newall, E., Schneider, U., Terbrueggen, A., Riebesell, U., 2005. Testing the direct effects of $\mathrm{CO}_{2}$ concentration on marine phytoplankton: a mesocosm experiment with the coccolithophorid Emiliania huxleyi. Limnology and Oceanography 50, 493-507.

Fernández, E., Boyd, P.W., Holligan, P.M., Harbour, D.S., 1993. Production of organic and inorganic carbon within a large-scale coccolithophore bloom in the northeast Atlantic Ocean. Marine Ecology-Progress Series 97, 271-285.

François, R., Honjo, S., Kirshfield, R., Manganini, S., 2002. Factors controlling the flux of organic carbon to the bathypelagic zone of the ocean. Global Biogeochemical Cycles 16, 1-20.

Garcia, C.M., Prieto, L., Echevarria, F., Garcia-Lafuente, J., Ruiz, J., Ruiz, J., Rubin, J.P., 2002. Hydrodynamics and the spatial distribution of plankton and TEP in the Gulf of Cadiz (SW Iberian Peninsula). Journal of Plankton Research 24, 817-833.

Grasshoff, K., Ehrhardt, M., Kremling, K., 1983. Methods of Seawater Analysis. Verlag Chemie.

GREPMA, 1988. Satellite (AVHRR:NOAA-9) and ship studies of a coccolithophorid bloom in the western English Channel. (Viollier, M., Sournia, A., Birrien, M.-J., Chrétiennot-Dinet, P., Le Borgne, P., Le Corre, P., Morin, P., and Olry, J. P.). Marine Nature 1 (1), 1-14.

Grossart, H.-P., Simon, M., Logan, B.E., 1997. Formation of macroscopic organic aggregates (Lake snow) in a large lake: the significance of transparent exopolymer particles, phytoplankton, and zooplankton. Limnology and Oceanography 42, 1651-1659.

Holligan, P.M., Fernández, E., Aiken, W., Balch, W.M., Boyd, P.W., Burkill, P.H., Finch, M., Groom, S.B., Malin, G., Muller, K., Purdie, D.A., Robinson, C., Trees, C.C., Turner, S.M., van der Wal, P., 1993a. A biogeochemical study of the coccolithophore, Emiliania huxleyi, in the North Atlantic. Global Biogeochemical Cycles 7, 879-900.

Holligan, P.M., Groom, S.B., Harbour, D.S., 1993b. What controls the distribution of the coccolithophore Emiliania huxleyi in the North Sea? Fisheries Oceanography 2, 175-183.

Holligan, P.M., Viollier, M., Harbour, D.S., Camus, P., Champagne-Philippe, M., 1983. Satellite and ship studies of coccolithophore production along a continental shelf edge. Nature 304, 339-342.

Huthnance, J.M., Coelho, H., Griffiths, C.R., Knight, P.J., Rees, A.P., Sinha, B., Vangriesheim, A., White, M., Chatwin, P.G., 2001. Physical structures, advection and mixing in the region of Goban spur. Deep Sea Research Part II: Topical Studies in Oceanography 48, 2979-3021.

Iglesias-Rodriguez, M.D., Brown, C.W., Doney, S.C., Kleypas, J., Kolber, D.D., Kolber, Z., 2002. Representing key phytoplankton functional groups in ocean carbon cycle models: coccolithophorids. Global Biogeochemical Cycles, doi:10.1029/2001GB001454.

Jacquet, S., Heldal, M., Iglesias-Rodriguez, M.D., Larsen, A., Wilson, W., Bratbak, G., 2002. Flow cytometric analysis of an Emiliania huxleyi bloom terminated by viral infection. Aquatic Microbial Ecology 27, 111-124.
Joint, I., Wollast, R., Chou, L., Batten, S., Elskens, M., Edwards, E., Hirst, A. Burkill, P.H., Groom, S., Gibb, S., Miller, A., Hydes, D.J., Dehairs, F. Antia, A.N., Barlow, R., Rees, A., Pomroy, A., Brockmann, U., Cimmings, D., Lampitt, R., Loijens, M., Mantoura, F., Miller, P., Raabe, T., AlvarezSalgado, X., Stelfox, C., Woolfenden, J., 2001. Pelagic production at the Celtic Sea shelf break. Deep Sea Research Part II: Topical Studies in Oceanography 48, 3049-3081.

Kahl, L.A., Vardi, A., Schofield, O., 2008. Effects of phytoplankton physiology on export flux. Marine Ecology-Progress Series 354, 3-19.

Klaas, C.M., Archer, D.E., 2002. Association of sinking organic matter with various types of mineral ballast in the deep sea: implications for the Rain Ratio. Global Biogeochemical Cycles 16.

Kepkay, P.E., 1994. Particle aggregation and the biological reactivity of colloids. Marine Ecology-Progress Series 109, 293-304.

Krembs, C., Engel, A., 2001. Abundance and variability of microorganisms and transparent exopolymeric particles across the ice-water interface of melting first year sea ice in the Laptev Sea (Arctic). Marine Biology 138, 173-185.

Leppard, G.G., 1995. The characterization of algal and microbial mucilages and their aggregates in aquatic ecosystems. Science of the Total Environment 165, 103-131.

Linschooten, C., van Bleijswijk, J.D.L., Van Emburg, P.R., De Vrind, J.P.M., Kempers, E.S., Westbroek, P., De Vrind-De Jong, E.W., 1991. Role of light-dark cycle and medium composition on the production of coccoliths by Emiliania huxleyi (Haptophyceae). Journal of Phycology 27, 82-86.

Logan, B.E., Passow, U., Alldredge, A.L., Grossart, H.-P., Simon, M., 1995 Rapid formation and sedimentation of large aggregates is predictable from coagulation rates (half-lives) of transparent exopolymer particles (TEP). Deep Sea Research Part II: Topical Studies in Oceanography 42, 203-214.

Mari, X. 1999. Carbon content and C:N ratio of transparent exopolymeric particles (TEP) produced by bubbling exudates of diatoms. Marine Ecology-Progress Series 183, 59-71.

Mari, X., Beauvais, S., Lemee, R., Pedrotti, M.L., 2001. Non-Redfield C:N ratio of transparent exopolymeric particles in the northwestern Mediterranean Sea. Limnology and Oceanography 46, 1831-1836.

Mari, X., Burd, A., 1998. Seasonal size spectra of transparent exopolymeric particles (TEP) in a coastal sea and comparison with those predicted using coagulation theory. Marine Ecology-Progress Series $163,63-76$.

Mari, X. Kiorboe, T., 1996. Abundance, size distribution and bacterial colonization of transparent exopolymeric particles (TEP) during spring in the Kattegat. Journal of Plankton Research 18, 969-986.

McCave, I.N., Hall, I.R., Antia, A.N., Chou, L., Dehairs, F., Lampitt, R.S. Thomsen, L., van Weering, T.C.E., Wollast, R., 2001. Distribution, composition and flux of particulate material over the European margin at $47^{\circ}-50^{\circ} \mathrm{N}$. Deep Sea Research Part II: Topical Studies in Oceanography 48, 3107-3139.

Myklestad, S.M., 1995. Release of extracellular products by phytoplankton with special emphasis on polysaccharides. Science of the Total Environment 165, 155-164.

O'Reilly, J.E., Maritorena, S., Mitchell, B.G., Siegel, D.A., Carder, K.L Garver, S.A., Kahru, M., McClain, C., 1998. Ocean color chlorophyll algorithms for SeaWiFS. Journal of Geophysical Research-Oceans 103 , 24937-24953.

Paasche, E., 2002. A review of the coccolithophorid Emiliania huxley (Prymnesiophyceae), with particular reference to growth, coccolith formation, and calcification-photosynthesis interactions. Phycol 40, 503-529.

Passow, U., 2002. Transparent exopolymer particles (TEP) in aquatic environments. Progress in Oceanography 55, 287-333.

Passow, U., Alldredge, A.L., 1995a. A dye-binding assay for the spectrophotometric measurement of transparent exopolymer particles (TEP). Limnology Oceanography 40, 1326-1335.

Passow, U., Alldredge, A.L., 1995b. Aggregation of a diatom bloom in a mesocosm: the role of transparent exopolymer particles (TEP). Deep Sea Research Part II: Topical Studies in Oceanography 42, 99-109.

Prieto, L., Navarro, G., Cozar, A., Echevarria, F., Garcia, C.M., 2006. Distribution of TEP in the euphotic and upper mesopelagic zones of the southern Iberian coasts. Deep Sea Research Part II: Topical Studies in Oceanography 53, 1314-1328.

Radic, T., Kraus, R., Fuks, D., Radic, J., Pecar, O., 2005. Transparent exopolymeric particles' distribution in the northern Adriatic and their relation to microphytoplankton biomass and composition. Science of the Total Environment 353, 151-161.

Riegman, R. Stolte, W., Nooderloos, A.A.M., Slezak, D., 2000. Nutrien uptake and alkaline phosphatase (ec 3:1:3:1) activity of Emiliania 
huxleyi (prymnesiophyceae) during growth under $\mathrm{N}$ and $\mathrm{P}$ limitation in continuous cultures. Journal of Phycology 36, 87-96.

Schartau, M., Engel, A., Schröter, J., Thoms, S., Völker, C., Wolf-Gladrow, D., 2007. Modelling carbon overconsumption and the formation of extracellular particulate organic carbon. Biogeosciences Discussions 4, 13-67.

Shackelford, R., Cowen, J.P., 2006. Transparent exopolymer particles (TEP) as a component of hydrothermal plume particle dynamics. Deep Sea Research Part I: Oceanographic Research Papers 53, 1677-1694.

Sugimoto, K., Fukuda, H., Baki, M.A., Koike, I., 2007. Bacterial contributions to formation of transparent exopolymer particles (TEP) and seasonal trends in coastal waters of Sagami Bay, Japan. Aquatic Microbial Ecology 46, 31-41.

Tyrrell, T., Merico, A., 2004. Emiliania huxleyi: bloom observations and the conditions that induce them. In: Thierstein, H.R., Young, J.R.
(Eds.), Coccolithophores. From molecular Processes to global Impact. Springer, Berlin, pp. 75-97.

Wollast, R., Chou, L., 2001. Ocean Margin EXchange in the Northern Gulf of Biscay: OMEX I. An introduction. Deep Sea Research Part II: Topical Studies in Oceanography 48, 2971-2978.

Wotton, R., 2004. The ubiquity and many roles of exopolymers (EPS) in aquatic systems. Scientia Marina 68, 13-21.

Wright, S.W., Jeffrey, S.W., 1997. High-resolution HPLC system for chlorophylls and carotenoids of marine phytoplankton. In: Jeffrey, S.W., Mantoura, R.F.C., Wright, S.W. (Eds.), Phytoplankton Pigments in Oceanography. UNESCO Publishing, pp. 327-341.

Yentsch, C.S., Menzel, D.W., 1963. A method for the determination of phytoplankton chlorophyll and phaeophytin by fluorescence. Deep Sea Research and Oceanographic Abstracts 10, 221-231. 